\title{
Mandatory Predispute Consumer Arbitration, Structural Bias, and Incentivizing Procedural Safeguards
}

Nancy A. Welsh

Texas A\&M University School of Law, nwelsh@law.tamu.edu

Follow this and additional works at: https://scholarship.law.tamu.edu/facscholar

Part of the Dispute Resolution and Arbitration Commons, and the Labor and Employment Law Commons

\section{Recommended Citation}

Nancy A. Welsh, Mandatory Predispute Consumer Arbitration, Structural Bias, and Incentivizing Procedural Safeguards, 42 Sw. L. Rev. 187 (2012).

Available at: https://scholarship.law.tamu.edu/facscholar/942

This Article is brought to you for free and open access by Texas A\&M Law Scholarship. It has been accepted for inclusion in Faculty Scholarship by an authorized administrator of Texas A\&M Law Scholarship. For more information, please contact aretteen@law.tamu.edu. 


\section{MANDATORY PREDISPUTE CONSUMER ARBITRATION, STRUCTURAL BIAS, AND INCENTIVIZING PROCEDURAL SAFEGUARDS}

Nancy A. Welsh*

\section{INTRODUCTION}

Within the past several decades, there has been an explosion in the creation, institutionalization and use of "alternative" dispute resolution procedures. Understood broadly, these procedures include formal and informal administrative adjudication, as well as arbitration, mediation and other court-connected and agency-connected innovations. In general, reformers conceived these "alternative" processes as means to end legal (or potentially legal) disputes and escape the perceived costs and inadequacies of traditional civil litigation and trials. Over the years, and perhaps counterintuitively, courts have embraced these processes. Indeed, courts have become such advocates for these processes that they have mandated their use in litigation (in the case of court-connected mediation), enforced rules that make their use a condition precedent to court access (in the case of administrative adjudication), and enforced their use pursuant to contract

* William Trickett Faculty Scholar and Professor of Law, Penn State University, Dickinson School of Law. I wish to extend heartfelt thanks to those who participated in workshops at the AALS ADR Section's annual conference, University of Missouri School of Law, Fordham University School of Law and the AALS Works-in-Progress Symposium at Ohio State University, Moritz College of Law for their insights and questions, with special thanks to John Lande, Jacqueline Nolan-Haley, Ron Aronovsky and Catherine Rogers. I am very grateful for the excellent research assistance provided by David Brown, Kevin Schock, and Katie Rimpfel. And final thanks must be given to Penn State University, Dickinson School of Law, and Dean Philip McConnaughay for the research funds that have helped to support my research. Any mistakes are, of course, my own. Portions of this article expand upon ideas presented in a prior blog posting that can be found at: Nancy Welsh, Is The Supreme Court Demanding Enough As It Provides Incentives For The Private Funding of a Federal Small Claims Court?, SCOTUSblog (Sep. 21, 2011, 2:13 PM), http://www.scotusblog.com/2011/09/is-the-supreme-court-demanding-enoughas-it-provides-incentives-for-the-private-funding-of-a-federal-small-claims-court/. 
terms imposed by repeat players upon one-shot players (in the case of mandatory predispute arbitration).

It is that last "alternative" process-mandatory predispute arbitrationthat has generated the most controversy because it appears beset with structural bias. The recent cases of AT\&T Mobility LLC v. Concepcion and CompuCredit Corp. v. Greenwood have raised additional concerns as the Supreme Court has announced that corporations can force consumers to arbitrate their private and statutory claims and give up their rights to pursue class relief. It is difficult to find a principled basis for the Court's decisions.

This Article argues, however, that the Supreme Court's enthusiastic embrace of mandatory predispute arbitration should be understood primarily as institutional self-help, as an opportunistic search for the funding and personnel that courts need to conduct fact-finding and decision-making in cases that the courts perceive as routine. If Congress and state legislatures will not provide such funding, perhaps corporations will. By permitting corporations to impose class waivers on consumers, the Supreme Court is incentivizing the corporations to provide and fund a national private small claims court. If the Court is incentivizing in this way, however, this Article urges that it should demand more in return for class waiver. Specifically, it should demand evidence that the arbitration procedure is sufficiently attractive to consumers so that they will pursue their claims, as well as evidence that the procedure is sufficiently fair. One difficulty in making these demands, however, is that courts are obligated to use very limited grounds and a deferential standard of review for arbitral awards.

Second, therefore, this Article urges courts to mine past experience in other legal contexts that involve privatized judicial functions, a deferential standard of judicial review and the incentivizing of procedural safeguards. A previous article explored the possibility that judges could apply the procedural due process jurisprudence-directly or indirectly- to mandatory pre-dispute consumer arbitration to help ensure that individual arbitrators, and the dispute resolution organizations that employ or contract with them, will "hold the balance [sufficiently] nice, clear and true."1 This Article turns to the trust law and ERISA contexts for guidance.

Specifically, this Article looks to the Supreme Court case of Metropolitan Life Insurance Co. v. Glenn ${ }^{2}$ and its progeny to examine the

1. See Nancy A.Welsh, What is "(Im)Partial Enough" in a World of Embedded Neutrals?, 52 ARIZ. L. REV. 395, 443 (2010) (citing to Tumey v. Ohio, 273 U.S. 510, 532 (1927) and Caperton v. A.T. Massey Coal Co., 129 S. Ct. 2252, 2265 (2009)).

2. 554 U.S. 105 (2008). 
evolution of the deferential standards of review that courts apply to ERISA plan benefit denials by private claims administrators, particularly when such administrators operate in a conflicted decision-making context. In this context, the Supreme Court has managed to acknowledge the existence of structural bias and make it a relevant and important factor to be considered as part of deferential judicial review. Further, the Supreme Court has provided guidance to lower courts regarding the weight to be given to structural bias in this context and has provided examples of the information required to assess such weight. Structural bias has been given the stature of tiebreaker in close cases. Finally and most important for the purposes of this Article, the Supreme Court has also incentivized the provision of structural and procedural safeguards in order to reduce the potency of the structural incentives that encourage biased decision-making. In other words, the Supreme Court has incentivized the provision of safeguards that will enhance the likelihood of accurate decision-making-all while maintaining a deferential standard of review.

Corporations continue to experiment with mandatory predispute arbitration clauses. The clause at issue in Concepcion, for example, permitted consumers to bring their claims in small claims court rather than arbitration and incorporated a monetary sanction if AT\&T failed to make a good faith settlement offer prior to arbitration. Are these sorts of provisions, by themselves, sufficient to overcome the potential for structural bias? Glenn provides a model for considering these provisions and their sufficiency as procedural safeguards, even while retaining a deferential standard of review. And importantly, in order to assess whether a clause like the one at issue in Concepcion sufficiently reduced potential bias and promoted accuracy, a court using Glenn's model likely would permit discovery regarding the actual implementation of the clause's key provisions. Glenn thus demonstrates the potential for incentivizing the development of improved provisions.

\section{THE RECENT ARBITRATION JURISPRUDENCE OF CONCEPCION AND COMPUCREDIT}

The Supreme Court's most recent additions to its arbitration jurisprudence involved strikingly small claims. ${ }^{3}$ In AT\&T Mobility $L L C v$. Concepcion, ${ }^{4}$ decided in 2011 , the Concepcions alleged that a cell phone company had engaged in false advertising by describing a cell phone as free

3. CompuCredit Corp. v. Greenwood, 132 S. Ct. 665 (2012); AT\&T Mobility LLC v. Concepcion, 131 S. Ct. 1740 (2011).

4. AT\&T Mobility v. Concepcion, 131 S. Ct. 1740 (2011) 
when, in fact, consumers would be required to pay state taxes. ${ }^{5}$ Those taxes amounted to a mere $\$ 30.22{ }^{6}$ In CompuCredit Corp. v. Greenwood, ${ }^{7}$ decided in 2012, the plaintiffs alleged that a credit repair organization had similarly defrauded consumers when it advertised a credit card as available at no cost and with an upfront credit line of $\$ 300$ when, in fact, consumers would be charged immediately with a finance fee, monthly fee and annual fee. ${ }^{8}$ In Wanda Greenwood's case, these three fees added up to $\$ 257,{ }^{9}$ thus depriving her (and the other consumers with a weak credit rating to whom this card was advertised) of all but $\$ 43$ of the upfront credit line they anticipated. $^{10}$

Cases with so little at stake hardly seem worthy of the attention of the Supreme Court. But, of course, both Concepcion and CompuCredit involved something more. The consumer contracts at issue in both cases contained mandatory predispute arbitration clauses, each with a provocative legal twist, and claims brought on behalf of a large class of consumers. ${ }^{11}$ Small individual claims translate into astonishingly large stakes when aggregated in this way. ${ }^{12}$ In Concepcion, the arbitration clause in the contract between AT\&T and the Concepcions permitted the Concepcions to bring their claims only on an individual basis, however, and then only in arbitration or small claims court. ${ }^{13}$ Thus, the clause required these consumers' waiver of their right to pursue redress through a class action. ${ }^{14}$ The Supreme Court determined that the state law of unconscionability that had been developed to bar such waiver was preempted by the Federal Arbitration Act ("FAA"). 15

The contract between CompuCredit and Ms. Greenwood similarly involved both an arbitration clause and class action, but the question at issue was whether the federal Credit Repair Organizations Act

5. Id. at 1744 .

6. Id.

7. CompuCredit Corp. v. Greenwood, 132 S. Ct. 665 (2012).

8. Id. at 676 (Ginsburg, J., dissenting).

9. Id.

10. It must be acknowledged, of course, that these consumers were left with a credit line of $\$ 43$ when they likely had little to no credit available to them before they contracted with CompuCredit. Id. at 676-77.

11. See id. at 668; Concepcion, $131 \mathrm{~S}$. Ct. at $1744-45$.

12. See CompuCredit, 132 S. Ct. 665; Concepcion, 131 S. Ct. 1740.

13. Concepcion, $131 \mathrm{~S}$. Ct. at 1744.

14. Id. at $1744-45$.

15. Id. at 1746,1753 . 
("CROA")-and, specifically, the provision ${ }^{16}$ in CompuCredit's contract that Ms. Greenwood had the "right to sue" under the CROA-limited the credit company's ability to establish arbitration as the exclusive forum in which a consumer could "sue.", Writing the majority opinion, Justice Scalia asserted that most consumers would understand this "colloquial" language as providing them with the "legal right, enforceable in court, to recover damages from credit repair organizations that violate the CROA"18 and, further, that their understanding would be "without regard to whether the suit in court has to be preceded by an arbitration proceeding[.]"19 On this basis, the Supreme Court concluded that consumers' right to access public courts could and should then be limited to "judicial action compelling or reviewing initial arbitral adjudication." 20 These empiricallyunsupported assertions regarding consumers' understanding of the sequence of legal procedures to be used to implement the protections of the CROA, combined with the statute's failure to include an explicit bar on the use of arbitration, ${ }^{21}$ paved the way for the Supreme Court's decision that the FAA required the enforcement of the terms of the arbitration clause at issue. ${ }^{22}$

Concepcion in particular was followed by a flood of commentary ${ }^{23}$ and cases. ${ }^{24}$ Professor Jean Sternlight recently provided a helpful survey of case

16. Importantly, this provision was included because it was a mandatory disclosure under the CROA.

17. CompuCredit, 132 S. Ct. at 668-71.

18. Id. at 672 (emphasis added).

19. Id.

20. Id. at 671; Professors Marc Galanter and John Lande have observed that "virtually all 'private courts' contain significant public elements" such as a reliance on public courts for enforcement of private awards. Marc Galanter \& John Lande, Private Courts and Public Authority, 12 STUD. IN LAW, POL. \& SOC'Y 393, 394 (1992).

21. The Supreme Court has emphasized the need to look to a federal statute's text or legislative history to determine whether arbitration is permitted. See, e.g., CompuCredit, $132 \mathrm{~S}$. Ct. at 675 (Sotomayor, J., concurring) ("As the majority opinion notes, the disclosure provision does not itself confer a cause of action, and the liability provision that does is materially indistinguishable from other statutes that we have held not to preclude arbitration. In my mind this leaves the parties' arguments in equipoise, and our precedents require that petitioners prevail in this circumstance. This is because respondents, as the opponents of arbitration, bear the burden of showing that Congress disallowed arbitration of their claims, and because we resolve doubts in favor of arbitration."); see also Gilmer v. Interstate/Johnson Lane Corp., 500 U.S. 20, 26 (1991) (discussing need to look to federal statute to determine whether arbitration is permitted); Shearson/Am. Exp., Inc. v. McMahon, 482 U.S. 220, 227 (1987).

22. CompuCredit, $132 \mathrm{~S}$. Ct. at 673.

23. Interestingly, some of this commentary has tried to place Concepcion in perspective, in a manner that establishes Concepcion as part of a core "trilogy" for arbitration jurisprudence in much the same way that Celotex, Liberty Lobby and Matsushita have been described as summary judgment's core "trilogy." See, e.g., Thomas J. Stipanowich, The Third Arbitration Trilogy: StoltNielsen, Rent-A-Center, Concepcion and the Future of American Arbitration, 22 AM. REV. INT'L 
law following Concepcion to urge that the decision represents a "tsunami ... wiping out existing and potential consumer and employment class actions." 25 She concludes that Concepcion has so dramatically reduced corporations' assessment of the risk of litigation over the enforcement of arbitration clauses that many more corporations will be compelled to "impose arbitral class action waivers as a means to insulate themselves from class actions[.]"26 Her prescience may be evidenced by Microsoft's announcement during the summer that it will include an arbitration provision and class action waiver in many of its contracts, ${ }^{27}$ although there are also a few courts that are stepping forward to strike down class waivers. ${ }^{28}$ Both Concepcion and CompuCredit fit neatly into a larger picture of a Supreme Court that perceives mammoth class actions, and many individual civil rights lawsuits, as generating unproductive income for plaintiffs' and defense lawyers and needlessly disrupting the work of embattled government and business leaders, ${ }^{29}$ when our nation needs such leaders to focus their time and resources on re-energizing our economy and protecting us from potential security threats. ${ }^{30}$ In this picture, corporations

ARB. 323, 325 (2011); Judith Resnik, Comment, Fairness in Numbers: A Comment on AT\&T v. Concepcion, Wal-Mart v. Dukes, and Turner v. Rogers, 125 HARV. L. REV. 78, 80-81 (2011).

24. See, e.g., Cruz v. Cingular Wireless, LLC, 648 F.3d 1205, 1206-07 (11th Cir. 2011); Kaltwasser v. AT\&T Mobility LLC, 812 F.Supp. 2d 1042, 1044 (N.D. Cal. 2011).

25. Jean R. Stemlight, Tsunami: AT\&T Mobility LLC v. Concepcion Impedes Access to Justice, 90 OR. L. REV. 703, 704 (2012).

26. Id. at 718. See also Nancy A. Welsh, I Could Have Been a Contender: Summary Jury Trial as a Means to Overcome Iqbal's Negative Effects upon Pre-Litigation Communication, Negotiation, and Early Consensual Dispute Resolution, 114 PENN. ST. L. REV. 1149, 1156-57 (2010) (making a similar prediction that the Supreme Court's decisions in Ashcroft v. Iqbal, 556 U.S. 662 (2009) and Bell Atlantic Corp. v. Twombly, 550 U.S. 544 (2007) so dramatically reduce the risk of undergoing litigation and responses to discovery that companies will stop providing inhouse conflict management systems).

27. See David Lazarus, Microsoft to Prohibit Class Action Suits, L.A. TIMES, June 8, 2012, at $\mathrm{Bl}$.

28. See In re Am. Exp. Merchants' Litig., 667 F.3d 204, 219 (2d Cir. 2012), cert. granted, Am. Exp. Co. v. Italian Colors Restaurant, No. 12-133, 2012 WL 3096737 (U.S. Nov. 9, 2012); In re Elec. Books Antitrust Litig., No. 11 MD 2293 (DLC), 2012 WL 2478462, at *3 (S.D.N.Y. June 27, 2012).

29. See Welsh, I Could Have Been a Contender, supra note 26, at 1156.

30. See id. at 1184-85 (examining Justice Souter's majority opinion in Twombly and Justice Kennedy's opinion in Iqbal); Jeffrey J. Rachlinski, Why Heightened Pleading-Why Now?, 114 PENN. ST. L. REV. 1247, 1252-53 (2010) (understanding Iqbal as a signal of deference to national institutions); see also Carrie Menkel-Meadow, Why Hasn't the World Gotten to Yes? An Appreciation and Some Reflections, 22 NEGOT. J. 485, 498 (2006) ("Does the larger zeitgeist in which we live (Cold War, economic boom and bust, globalization, the War on Terror) affect how we conceptualize the world and what we do? Is Getting to Yes and its progeny a product of its time or a more universal expression of what might be possible, of what might be achieved?"). 
and the Court are merely making opportunistic use of arbitration and the FAA's protective shield, to camouflage the "troll" of class waiver."

But there is another way to understand Concepcion and CompuCredit. This view has much less to do with solicitousness toward corporations, governmental institutions and authority ${ }^{32}$ and much more to do with the federal judiciary's status as the "weakest" and "least dangerous" 33 of the three branches of government.

\section{INCENTIVIZING CORPORATE FUNDING OF A PRIVATIZED SMALL Claims COURT}

Both Concepcion and CompuCredit have the potential to be understood as the Supreme Court's self-help answer to a Congress and state legislatures that continue to funnel more civil and criminal cases to the courts ${ }^{34}$ and require annual reports regarding the efficiency of the courts' docket management ${ }^{35}$ while simultaneously underfunding and understaffing them. $^{36}$ The Supreme Court has engaged in such self-help before. Long ago, the institution slowed the pace of its decisions when Congress required Supreme Court justices to resume riding circuit without a corresponding

31. Arbitration was not designed for this purpose. It is a valuable process that was developed to meet the real needs of contracting parties. See Nancy A.Welsh, What is "(Im)Partial Enough" in a World of Embedded Neutrals?, 52 ARIZ. L. REV. 395, 467 (2010). It is tempting to reimagine arbitration as the rich but unpopular girl who is invited to the prom by the popular boy. She may be dazzled by the invitation and even imagine that the boy actually likes her. Actually, he is just using her to gain access to her car, her house, her pool, etc. See also JOHN STEINBECK, The Chrysanthemums, in THE LONG VALLEY 1 (Penguin Books 1995) (1938).

32. See Rachlinski, supra note 30 , at 1252-54.

33. THE FEDERALIST NO. 78, at 450 (Alexander Hamilton) (Am. Bar Ass'n ed., 2009). Hamilton argues that the judicial branch is undoubtedly the weakest of the three branches because it lacks the ability to "attack" the other branches, and has little ability to defend itself if the legislative or executive branch attempts to usurp those powers vested in the judicial branch.

34. See, e.g., Ingle v. Circuit City Stores, Inc., 328 F.3d 1165, 1169 (9th Cir. 2003) (denying defendant's motion to compel arbitration in response to plaintiff's action for violation of state and federal civil rights); Individuals with Disabilities Education Act, 20 U.S.C. $\$ \S 1400-1450$ (2006); Individuals with Disabilities Act of 1990, 42 U.S.C. $\$ \S 12101-12300$ (2006); Federal Question Jurisdictional Amendments Act of 1980, Pub. L. No. 96-486, 94 Stat. 2369 (removing the amount in controversy requirement for federal question jurisdiction).

35. See, e.g., FED. JUDICIAL CTR., ANNUAL REPORT (2011), available at http://www.fjc.gov/public/pdf.nsf/lookup/AnnRep11.pdf/\$file/AnnRep11.pdf; Chief Justice John G. Roberts, Jr., 2011 Year-End Report on the Federal Judiciary, THE THIRD BRANCH (Jan. 2012), http://www.uscourts.gov/News/TheThirdBranch/12-01-01/2011_Year-End_Report_on_the_ Federal_Judiciary.aspx.

36. See Judith Resnik, Mediating Preferences: Litigant Preferences for Process and Judicial Preferences for Settlement, 2002 J. DISP. RESOL. 155, 162-63, 165 (2002); Judith Resnik, Trial as Error, Jurisdiction as Injury: Transforming the Meaning of Article III, 113 HARV. L. REV. 924, 998, $1011(2000)$. 
pay increase. ${ }^{37}$ More recently, some have argued that the federal courts have engaged in self-help as they have ordered parties to participate in mediation and other settlement-oriented processes - and have also ordered the parties to pay for the services of these mediators, special masters and other neutrals. ${ }^{38}$

With Concepcion, CompuCredit and other recent arbitration cases involving disparate parties, ${ }^{39}$ however, the Supreme Court is effectively incentivizing the development of a new sort of layer of adjunct judicial officers. ${ }^{40}$ More specifically, the Court seems to be using the incentive of class waiver to persuade corporations to fund a privatized national small claims court that can then handle the many routine consumer-related disputes that arise. ${ }^{41}$ Potentially, such a private court could mimic the

37. See James E. Pfander, Judicial Compensation and the Definition of Judicial Power in the Early Republic, 107 MiCH. L. REV. 1 (2008).

38. See Deborah Hensler, Our Courts, Ourselves: How the Alternative Dispute Resolution Movement Is Reshaping Our Legal System, 108 PENN. ST. L. REV. 165, 195 (2003); Nancy A. Welsh, The Place of Court-Connected Mediation in a Democratic Justice System, 5 No. 2 CARDozo J. CONFLICT. RESOL. 117 (2004). It is important to recall, however, that Congress required the federal courts to institutionalize mediation and other dispute resolution procedures in the Civil Justice Reform Act of 1990. See 28 U.S.C. $\$ 471-82$ (2006).

39. See Thomas E. Carbonneau, Arguments in Favor of the Triumph of Arbitration, 10 CARdozo J. CONFLICT RESOL. 395, 398 (2009) (referring to arbitration agreements involving consumers and non-unionized employees as "disparate-party" arbitration); Theodore Eisenberg et al., Arbitration's Summer Soldiers: An Empirical Study of Arbitration Clauses in Consumer and Non-Consumer Contracts, 41 U. MICH. J.L. REFORM 871, 871, 895 (2008) (reporting empirical findings that corporations are much more likely to insert arbitration clauses in contracts with consumers and employees than in contracts with other corporations).

40. In response to a Congressional mandate, the federal district and circuit courts have overtly established a layer of adjunct, privatized settlement facilitators-i.e., mediators on court rosters or selected independently by the parties. See Alternative Dispute Resolution Act, 28 U.S.C. $\S 652$ (a) (2006). Interestingly, in this context, courts have not incentivized parties' use and funding of mediation. Rather, courts have mandated such use of mediation and other "nonbinding" dispute resolution processes. Districts also may mandate payment of the mediators. See Nancy A. Welsh, The Place of Court-Connected Mediation in a Democratic Justice System, 5 CARdozo J. CONFLiCT Resol. 117, $137-39$ (2004). See also Nancy A. Welsh and Andrea K. Schneider, The Thoughtful Integration of Mediation into Investment Treaty Arbitration, _ HARV. NEGOT. L. REV. _ (describing variations of "mandatory" mediation in the U.S., as well as incentives provided elsewhere) (forthcoming).

41. One irony is that while the Supreme Court is thus seeking to "outsource" small claims, various states have established new business courts designed to woo corporations and their commercial jurisprudence back into the public courts. See Christopher R. Drahozal, Business Courts and the Future of Arbitration, 10 CARDOZO J. CONFLICT RESOL. 491, 506-07 (2009) (describing business courts and finding no evidence that such courts are taking commercial business from arbitration); John Coyle, Business Courts and Interstate Competition, 53 WM. \& MARY L. REV. 1915, 1919-20 (2012). Meanwhile, some well-respected business courts have begun to offer for-fee arbitration services themselves, with the blessing of their legislatures. See, e.g., Gregory P. Williams et al., Securities Litigation: Arbitration in the Delaware Court of Chancery, 25 INSIGHTS: THE CORPORATE \& SECURITIES LAW ADVISOR 2 (July 2011). But see 
expedited procedures and in-person nature of the small claims courts ${ }^{42}$ found in public courthouses and office buildings around the country. ${ }^{43}$ More likely, a private court of this sort would adapt the settlement-focused approaches used in well-run corporate customer service and compliance departments $^{44}$ and take advantage of technological platforms that enhance efficiency and overcome geographic limitations-e.g., online procedures, ${ }^{45}$ telephonic ${ }^{46}$ or video conferenced ${ }^{47}$ hearings, procedures based exclusively on paper submissions, ${ }^{48}$ etc. $^{49}$

It would not be illogical to conclude that expensive, procedure-laden public courts are not needed to process routine consumer matters. Research, after all, shows that creditors' debt collection claims, not consumer-initiated claims, dominate the dockets of small claims courts and

Delaware Coalition for Open Government v. Strine, No. 1:11-1015, 2012 WL 3744718 (D.Del. Aug. 30, 2012).

42. See, e.g., Bruce Zucker \& Monica Her, The People's Court Examined: A Legal and Empirical Analysis of the Small Claims Court System, 37 U.S.F. L. REV. 315, 317 (2003). Also referred to as conciliation courts, small claims part courts, commercial small claims courts, minor courts and municipal courts. See, e.g., RALPH WARNER, EVERYBODY'S GUIDE TO SMALL CLAIMS COURT (14th ed. 2012).

43. Small-claims courts are often caricatured on television programs such as Judge Judy. See Zucker \& Her, supra note 42 , at 322-23. In actuality, Judge Judy offers a form of arbitration. See Joshua S. Wilson \& Erin Ackerman, "Tort Tales" and TV Judges: Amplifying, Modifying, or Countering the Antitort Narrative?, 46 LAW \& SoC'Y REV. 105, 112 (2012).

44. See Dusty Bates Farned, A New Automated Class of Online Dispute Resolution: Changing the Meaning of Computer Mediated Communication, 2 FAULKNER L. REV. 335 (2011); Colin Rule and Chittu Nagarjan, Leveraging the Wisdom of Crowds: The eBay Community Court and the Future of Online Dispute Resolution, AC RESOLUTION (Winter 2010).

45. Louis Del Duca et al., Facilitating Expansion of Cross-Border E-Commerce Developing a Global Online Dispute Resolution System (Lessons Derived from Existing ODR Systems - Work of the United Nations Commission on International Trade Law), 1 PENN. ST. J.L. \& INT'L AFF. 59 (2012); M. Ethan Katsh, Dispute Resolution in Cyberspace, 28 CONN. L. REV. 953 (1996); Oma Rabinovich-Einy, Technology's Impact: The Quest for a New Paradigm for Accountability in Mediation, 11 HARV. NEGOT. L. REV. 253 (2006); Orna Rabinovich-Einy \& Ethan Katsh, Technology and the Future of Dispute Systems Design, 17 HARV. NEGOT. L. REV. 151, 164-193 (2012); Colin Rule et al., Designing a Global Consumer Online Dispute Resolution (ODR) System for Cross-Border Small Value-High Volume Claims-OAS Developments, 42 UCC L.J. 221 (2010); Amy Schmitz, "Drive-Thru" Arbitration in the Digital Age: Empowering Consumers Through Binding ODR, 62 BAYLOR L. REV. 178 (2010).

46. See, e.g., Schmitz, supra note 45 , at 195 n. 110.

47. See id. at $\mathbf{1 8 6 .}$

48. See id. at 209 n. 192; Mark Spottswood, Live Hearings and Paper Trials, 38 FLA. ST. U. L. REV. 827,829 (2011).

49. It is difficult to avoid noticing a similar enthusiasm among public universities for online delivery of educational services, which has achieved significant success in the private sector. Richard Pérez-Peña, Ousted Head of University is Reinstated in Virginia, N.Y. TIMES, June 27, 2012, at A13. 
private consumer arbitration ${ }^{50}$ (and, presumably, the income received by both types of tribunals in filing fees). ${ }^{51}$ In a majority of these cases, whether they are arbitrated or litigated, consumers owe the monies claimed and either default ${ }^{52}$ or lose on the merits. ${ }^{53}$ As state and federal courts face severe budget cuts, why not allow the affected corporations to elect and pay $^{54}$ for alternative, more efficient private tribunals to handle such routine matters, with such predicable dynamics and results ${ }^{55}$

The answer to this question is relatively straightforward. Such a transformation inevitably triggers serious constitutional concerns regarding the fundamental right of access to, and protections afforded by, our public

50. See Sarah Rudolph Cole, On Babies and Bathwater: The Arbitration Fairness Act and the Supreme Court's Recent Arbitration Jurisprudence, 48 HouS. L. REV. 457 (2011); Christopher R. Drahozal \& Samantha Zyontz, Creditor Claims in Arbitration and in Court, 7 Hastings BUS. L.J. 77, 77 n.1 (2011); Sternlight, Tsunami, supra note 25, at 723-24 (referencing research regarding the consumers' initiation of arbitration proceedings against AT\&T Mobility and First USA); see also Thomas J. Stipanowich, Nancy Welsh, Lisa Blomgren Bingham \& Larry Mills, National Roundtable on Consumer and Employment Dispute Resolution: Consumer Arbitration Roundtable Summary Report, PENN STATE LAW RES. PAPER No. 18-2012, APRIL 17, 2012, at 7.

51. But see, e.g., Ethan Bronner, Poor Land in Jail as Companies Add Huge Fees for Probation, N.Y. TIMES, July 3, 2012, at Al (describing how the courts and companies are requiring significant payments from the poor); JAMES Q. WHITMAN, HARSH JUSTICE: CRIMINAL Punishment AND THE WIDENING DIVIDE BETWEen AMERICA AND EuROPE 97-98 (2003) (surveying the history of the treatment of high-status prisoners in France and Germany).

52. See FTC, REPAIRING A BROKEN SYSTEM: PROTECTING CONSUMERS IN DEBT COLLECTION LITIGATION AND ARBITRATION 41-44 (2010) (reporting incidence of default and problems with provision of notice to consumers); Cole, Babies and Bathwater, supra note 50, at 472 n. 50 .

53. See, e.g., Cole, Babies and Bathwater, supra note 50, at 472 n.50; Sarah R. Cole and \& Kristen M. Blankley, Empirical Research on Consumer Arbitration: What the Data Reveals, 113 PENN ST. L. REV. 1051 (2009).

54. There is some indication, however, that corporations are reducing this financial obligation by imposing fee-shifting upon consumers who lose in arbitration. See Miles B. Farmer, Mandatory and Fair? A Better System of Mandatory Arbitration, 121 YALE L.J. 2346, 2355-56 (2012) (citing Jean R. Sternlight, Creeping Mandatory Arbitration: Is it Just?, 57 STAN. L. REV. $1631,1649-50$ (2005)). Others have noted that in this and other ways, the U.S. common law and adversarial approach to litigation seems to give way to an approach that is mimicking the Continental civil law inquisitorial approach (involving less discovery and greater incidence of feeshifting). See Gillian K. Hadfield, Where Have All the Trials Gone? Settlements, Nontrial Adjudications, and Statistical Artifacts in the Changing Disposition of Federal Civil Cases, $1 \mathrm{~J}$. EMPIRICAL Legal STUD. 705, 733 (2004); James R. Maxeiner, Pleading and Access to Civil Procedure: Historical and Comparative Reflections on lqbal, a Day in Court and a Decision According to Law, 114 PENN. ST. L. REV. 1257, 1259 (2010).

55. See Maurits Barendrecht, Courts, Competition and Innovation, TIlbuRG LAW SCH. LEGAl Stud. RES. PAPER SERIES No. 003/2012, Sept. 27, 2011, at 11-12 (listing areas for improvement by courts that invite litigants to shop for other, more innovative forums). But see Drahozal, supra note 41, at 506-07 (finding little evidence that the innovation of business courts is luring litigants away from arbitration). 
courts. ${ }^{56}$ The vast majority of citizens and residents in the U.S., after all, are likely to be involved in only "small claims," resort to our public courts only infrequently, ${ }^{58}$ and need the procedural protections promised by the courts (even though the courts regularly fail, as do all creations of man, to deliver on their promises). ${ }^{59}$ Authorizing corporations to shape and fund a national small claims court through which consumers must navigate before they may access public courts, and then limiting such access to deferential judicial review, invites both the perception and the reality of a system that is beset by structural bias. Such perceptions then endanger the public's perception of the courts as a place where they can trust that they will experience justice. $^{60}$

56. See, e.g., U.S. v. Kras, 409 U.S. 434 (1973); Ortwein v. Schwab, 410 U.S. 656 (1973); Boddie v. Connecticut, 401 U.S. 371, 374-76 (1971); Wilcox Elec., Inc. v. F.A.A., 119 F.3d 724, 726-28 (8th Cir. 1997) (holding that the court could not review an agency award because the appellant lacked Article III standing).

57. See Warner, supra note 42. Further, as noted by Professor Sternlight, many consumers are unaware of these claims and are unlikely to bring an action, except as part of a class action. See Sternlight, Tsunami, supra note 25, at 722-23.

58. Of course, I am distinguishing here between repeat players (e.g., lawyers, insurers, certain corporations) and one-shot players (e.g., most individuals in the U.S.). Research has shown that most people, most of whom are one-shot players, are likely to take very few of their disputes to court for redress. See Marc Galanter, Access to Justice in a World of Expanding Social Capability, 37 FORDHAM URB. L.J. 115, 117-18 (2010) ("The central intellectual construct of the dispute perspective was the dispute pyramid - the notion that any sector of the legal world can be envisioned as a pyramid in which a base of troubles or injuries underlies a layer of perceived injuries, which leads in turn to successively smaller layers of grievances (injuries for which some human actor is viewed as responsible), claims, and disputes."); Marc Galanter, Why the "Haves" Come Out Ahead: Speculations on the Limits of Legal Change, 9 LAW \& SoC'Y REV. 96, 97-100 (1974) (noting the significant advantages that repeat players have over one-shot players); Leonard L. Riskin \& Nancy A. Welsh, Is That All There Is?: "The Problem" in Court-Oriented Mediation, 15 GEO. MASON L. REV. 863, 925-26 (2008) (describing civil litigation as a "once-in-a-lifetime" event for most people, who are thus one-shot players).

59. See Phyllis E. Bernard, Minorities, Mediation and Method: The View from One CourtConnected Mediation Program, 35 FordhaM URB. L.J. 1, 7, 36 (2008); Peter A. Holland, The One Hundred Billion Dollar Problem in Small Claims Court: Robo-Signing and Lack of Proof in Debt Buyer Cases, 6 J. BUS. \& TECH. L. 259, 265-66, 266 n.42 (2011) (discussing cases arising out of the foreclosure crisis and the processing of foreclosures even when paperwork was missing).

60. I have written elsewhere about the negative effect that structural bias almost certainly will have upon perceptions of procedural justice, particularly if parties are given no meaningful ability to avoid such bias. See Welsh, Embedded Neutrals, supra note 31 at 424-26; see also Welsh, Stepping Back Through the Looking Glass: Real Conversations with Real Disputants About the Place, Value and Meaning of Mediation, 19 OHIO ST. J. ON DISP. RESOL. 573, 648-50, 659-61 (reporting structural choices and mediator behaviors in special education mediation that led to perceptions of bias); Nancy Welsh, Perceptions of Fairness, in THE NEGOTIATOR'S FIELDBOOK 165, 171 (Andrea K. Schneider \& Christopher Honeyman, eds., 2006); Nancy Welsh, The Place of Court-Connected Mediation in a Democratic Justice System, 5 CARDOZO J. OF CONFLICT RESOL. 117, 131 (2004) (regarding structural bias). Perceptions of procedural justice matter. They influence perceptions of substantive justice, compliance with outcomes, and 
Further, if the Supreme Court's support for mandatory predispute disparate party arbitration and its accompanying opposition to consumers' class proceedings are indeed motivated by the justices' desire to establish a new layer of inferior, adjunct judicial officers, the use of arbitration jurisprudence as a backdoor funding mechanism raises many vexing questions. Some of these questions involve limits that the Constitution places upon the Court's institutional authority. ${ }^{61}$ Such questions are deserving of searching academic and legal attention.

This Article, however, will accept the premise that legislative encouragement of private attorneys general through plaintiff-friendly fee-

perceptions of the legitimacy of the institutions that provide dispute resolution and decisionmaking procedures. See E. Allan LIND \& TOM R. TYLER, THE SOCIAL PSYCHOLOGY OF Procedural Justice (1988); E. Allan Lind, Procedural Justice, Disputing, and Reactions to Legal Authorities, in EVERYDAY PRACTICES AND TROUBLE CASES 177 (Austin Sarat, et al. eds., 1998); Tom R. Tyler, Social Justice: Outcome and Procedure, 35 INT'L. J. PSYCHOL. 117 (2000); see also Nancy A. Welsh \& Andrea K. Schneider, The Thoughtful Integration of Mediation into Investment Treaty Arbitration, _ HARV. NEGOT. L. REV. _ (describing procedural justice literature, considering its relationship to dispute system design and applying it to the integration of mediation into investor-state dispute resolution) (forthcoming); Nancy A. Welsh, Donna Stienstra \& Bobbi McAdoo, The Application of Procedural Justice Research to Judicial Actions and Techniques in Settlement Sessions, in THE MULTI-TASKING JUdGE: COMPARATIVE JUdICIAL DISPUTE RESOlUTION (Tania Sourdin \& Archie Zariski, eds.) (forthcoming 2013); Barbara McAdoo \& Nancy A. Welsh, Look Before You Leap and Keep on Looking: Lessons from the Institutionalization of Court-Connected Mediation, 5 NEV. L. J. 399, 402 (describing generally the 1976 Pound Conference and three ABA presidents' defense of the courts as a place where people could get justice unavailable elsewhere); Nancy A. Welsh, Making Deals in Court-Connected Mediation: What's Justice Got To Do With It?, 79 WASH. U. L. Q. 787, 859-61 (2001); Nancy A. Welsh, Disputants' Decision Control in Court-Connected Mediation: A Hollow Promise Without Procedural Justice, 2002 J. DISP. RESOL. 179 (2002).

61. The Supreme Court certainly has the authority to interpret the jurisdiction of the federal district courts narrowly and wait for Congressional response-or acquiescence. See, e.g., Louisville \& Nashville Railroad Co. v. Mottley, 211 U.S. 149, 153 (interpreting 28 U.S.C. $\$ 1331$ to require the federal district courts' original jurisdiction to be pled in the complaint). See also Peter B. Rutledge, Arbitration and Article III, 61 VAND. L. REV. 1189, 1201 (2008) ("By mandating the enforcement of the award and controlling the scope of Article III review, particularly the extent of review of the merits of federal questions, Congress effectively is stripping federal courts of the power to interpret the meaning of federal law and erecting a system by which others, namely arbitrators, can define it. It also effectively is mandating that federal courts treat the result of this private dispute resolution system as a judgment of a federal court, with all of the accoutrements that accompany that judgment."). Even if the Supreme Court can thus engage in de facto federal jurisdiction stripping, what is the source of its authority for depriving state courts of their jurisdiction? Will the procedural protections of the Due Process Clause apply to a private court encouraged by the Supreme Court and funded in this manner? See Welsh, Embedded Neutrals, supra note 31; Richard C. Reuben, Constitutional Gravity: A Unitary Theory of Alternative Dispute Resolution and Public Civil Justice, 47 UCLA L. REV. 949 (2000); Richard C. Reuben, Democracy and Dispute Resolution: The Problem of Arbitration, 67 LAW \& CONTEMP. PROBS. 279 (2004). 
shifting ${ }^{62}$ and class actions ${ }^{63}$ is coming to a close-and is being replaced with judicial encouragement of, and apparent legislative acquiescence in, the creation of a privately-funded national small claims tribunal. What then?

\section{INCENTIVIZING PROCEDURAL SAFEGUARDS}

Concepcion and CompuCredit have created the conditions that now require courts to either find non-discriminatory ${ }^{64}$ bases for rejecting class waivers in the arbitration clauses ${ }^{65}$ in consumer contracts or counterbalance the rise of this new, privately-funded small claims court with equally-new procedural and structural safeguards. This Article will focus on the latter task. Such safeguards could be designed to enhance the likelihood of sufficient fairness during the fact-finding process-or at least reduce the likelihood of unfaimess and biased decision-making.

Importantly, work has already been done to develop such safeguards in the form of protocols and policies. ${ }^{66}$ Some of the most respected dispute

62. See, e.g., 42 U.S.C. $\$ 1988$ (2006); 42 U.S.C. $\$ 12205$ (2006); 29 U.S.C. $\S 2617$ (a)(3) (providing for one-way fee shifting in "family leave" cases); Civil Rights Act of 1964, 42 U.S.C. $\S 2000 \mathrm{e}-5(\mathrm{k})$ (2006); Americans with Disabilities Act of 1990, 42 U.S.C. $\$ 12205$ (2006); Age Discrimination in Employment Act of 1967, 29 U.S.C. $\$$ 626(b) (2006); Civil Rights Attorney's Fees Awards Act of 1976, 42 U.S.C. $\S 1988(\mathrm{~b})$ (2006); see also Judith Resnik, Money Matters 148 U. PA. L. REV. 2119 (2000).

63. See FED. R. CIV. P. 23. It must be noted that Congress has also acted to limit such availability. See, e.g., Class Action Fairness Act of 2005, Pub. L. No. 109-2, 119 Stat. 4 (codified as amended in scattered sections of 28 U.S.C.); Private Securities Litigation and Reform Act of 1995, Pub. L. No. 104-67, 109 Stat. 373 (codified as amended in scattered sections of 28 U.S.C.)

64. See Hiro Aragaki, AT\&T Mobility v. Concepcion and the Antidiscrimination Theory of Federal Arbitration Act Preemption, 4 Y.B. ARB. \& MED. 2012 (2012), available at http://papers.ssrn.com/sol3/papers.cfm?abstract_id=2046453; Hiro Aragaki, Equal Opportunity for Arbitration, 58 UCLA L. REV. 1189, 1192-94 (2011).

65. See In re Am. Exp. Merchants' Litig., 667 F.3d at 219; Elec. Books, 2012 WL 2478462, at *3.

66. The American Arbitration Association's administration of consumer arbitration is guided by the Consumer Due Process Protocol and the AAA's Consumer Rules Supplement. See National Consumer Disputes Advisory Committee, Consumer Due Process Protocol (1997), available at $\mathrm{http} / / \mathrm{www}$.adr.org/sp.asp?id=22019; National Task Force on the Arbitration of Consumer Debt Collection Disputes, Consumer Debt Collection Due Process Protocol Statement of Principles (2010), available at http://www.adr.org/si.asp?id=6248. JAMS, meanwhile, has developed its own policy for consumer arbitration. See JAMS Policy on Consumer Arbitrations Pursuant to Pre-Dispute Clauses: Minimum Standards of Procedural Fairness (2009), available at http://www.jamsadr.com/files/Uploads/Documents/JAMS-Rules/JAMS_Consumer_Min_Stds2009.pdf. See also Stipanowich et al., National Roundtable supra note 50 at $48-52$ (describing several consumer dispute resolution programs and models); Amy J. Schmitz, Curing Consumers' Warranty Woes Through Regulated Arbitration, 23 OHIO ST. J. ON DISPUTE RESOL. 627 (2008); Amy J. Schmitz, Legislating in the Light: Considering Empirical Data in Crafting Arbitration Reforms, 15 HARV. NEGOT. L. REV. 115 (2010). 
resolution providers abide by such protocols and policies. ${ }^{67}$ Although there are meaningful differences among them, ${ }^{68}$ there are also many commonalities in terms of their commitment to providing consumers with a neutral and convenient forum, access to information, and services at a reasonable cost. Some of these providers also have established special rules for class action arbitration. ${ }^{69}$ Indeed, at one point JAMS determined that it would not administer arbitration clauses containing class waivers. In the face of very negative reactions, however, JAMS revised its policy and will now administer such clauses. ${ }^{70}$

There is no guarantee that all arbitral providers will adopt procedural safeguards. Many of the terms are likely to reduce efficiency, at least on a short-term basis, and the story of JAMS' brief flirtation with refusing to enforce class waivers hints at the potential consequences that arbitral providers may suffer if they stand alone in taking a position that is unpopular with those choosing which arbitral providers to include in their boilerplate contracts. Essential procedural safeguards are much more likely to be adopted if courts establish incentives to encourage such behavior. ${ }^{71}$

67. See supra note 66; see also CPR-Georgetown Commission on Ethics and Standards of Practice in ADR, Principles for ADR Provider Organizations (2002), available at http:/www.cpradr.org/Resources/ALLCPRArticles/tabid/265/ID/623/Principles-for-ADRProvider-Organizations.aspx.

68. For example, Principle 5 of the Consumer Due Process Protocols used by the American Arbitration Association provides that consumer ADR agreements should permit consumers to seek relief in small claims court. JAMS Policy on Consumer Arbitrations, in contrast, does not provide for access to small claims court. See id. The Due Process Protocol and JAMS Policy on Consumer Arbitrations also vary in their assurance that consumers will have access in arbitration to all otherwise-available remedies. The Due Process Protocols provide that the arbitrator should be empowered to grant whatever relief would be available in court under law or in equity; the JAMS Policy on Consumer Arbitration does not provide for all such remedies if the consumer is permitted to pursue otherwise-unavailable remedies in court. Compare Principle 14 of the Due Process Protocols, supra note 66, with Standard 3 of the JAMS Policy, supra note 66.

69. See, e.g., JAMS Class Action Procedures (2009), available at http://www.jamsadr.com/rules-class-action-procedures/; AAA's Supplementary Rules for Class Actions (2003), available at http:/www.adr.org/aaa/faces/rules/searchrules/rulesdetail?doc= ADRSTG_004129\&_afrLoop $=756271851123260$ \&_afrWindowMode $=0$ \&_afrWindowld $=1 \mathrm{dph} 8 \mathrm{i}$ v9dz_193\#\%40\%3F_afrWindowId\%3D1dph8iv9dz_193\%26_afrLoop\%3D756271851123260\%2 6doc\%3DADRSTG_004129\%26_afrWindowMode\%3D0\%26_adf.ctrl-state\%3D1dph8iv9dz 218.

70. See Martin H. Malin, The Arbitration Fairness Act: An Idea That's Time Has Come?, 87 IND. L. J. 289, 312 (2012); JAMS Revises Procedures on Class Arbitration, Class ACTION NEWSLETTER (Schiff Hardin, L.L.P.), June 25, 2009; Alan S. Kaplinsky \& Mark J. Levin, Is JAMS in a Jam Over Its Policy Regarding Class Action Waivers in Consumer Arbitration Agreements?, 61 BUSINESS LAWYER 923 (2006).

71. See also, Farmer, supra note 54, at 2349 (proposing that "in addition to the threat of prosecution [by public attorneys], incentives and mechanisms should be created for arbitration providers and parties who use mandatory arbitration to make their systems of dispute resolution 
At this point, then, it is worth returning to the arbitration provision that was at issue in Concepcion. To begin, it is more accurate to describe this clause as a two-step or tiered dispute resolution provision that is remarkably similar to the provisions used to settle class actions in the past. ${ }^{72}$ Because of the procedural safeguards it contained, the average consumer might have found this clause quite appealing. ${ }^{73}$ To initiate a dispute proceeding, the consumer had only to complete a short online form on the AT\&T website. ${ }^{74}$ AT\&T could then offer to settle the claim. ${ }^{75}$ Thus, both AT\&T and the consumer could avoid the cost and time involved in pursuing arbitration.

If AT\&T did not make such an offer, or if the dispute was not resolved within thirty days, the consumer could then file a separate demand for arbitration, also through the website. ${ }^{76}$ The clause further provided that:

- If the parties went to arbitration, AT\&T had to pay all costs for non-frivolous claims; ${ }^{77}$

- The arbitration had to take place in the county in which the customer was billed; ${ }^{78}$

- For claims of $\$ 10,000$ or less, the customer could choose the form of the arbitration - in person, by telephone or based only on paper submissions; ${ }^{79}$

- Either the consumer or AT\&T could bring a claim in small claims court rather than arbitrate $;^{80}$

fairer"); Thomas J. Stipanowich, The Arbitration Fairness Index: Using A Public Rating System to Skirt the Legal Logjam and Promote Fairer and More Effective Arbitration of Employment and Consumer Disputes, 60 U. KAN. L. REV. 985, 991 (2012) (proposing a privately-developed and privately-administered rating system to incentivize procedural safeguards).

72. See Nancy Welsh \& Judge Ann Montgomery, Grappling the Monster Case: The Next Frontier in ADR, 54 BENCH \& BAR OF MINNESOTA 21 (Sept. 2007); Francis E. McGovern, The What and Why of Claims Resolution Facilities, 57 STAN. L. REV. 1361, 1368-70 (2005) (describing procedures used to resolve mass torts and class actions); Francis H. McGovern, Settlement of Mass Torts in a Federal System, 36 WAKE FOREST L. REV. 871, 885 (2001) (describing procedural options in A. H. Robins case); see also Peter Salem, The Emergence of Triage in Family Court Services, the Beginning of the End for Mandatory Mediation, 47 FAM. CT. REV. 371 (2009); Peter Salem et al., Triaging Court Services: The Connecticut Judicial Branch's Family Civil Intake Screen, 27 PACE L. REV. 741 , 749 (2006-2007).

73. See Concepcion, $131 \mathrm{~S}$. Ct. at $\mathbf{1 7 5 3 .}$

74. Id. at 1744 .

75. Id.

76. $I d$.

77. $I d$.

78. Id.

79. Id.

80. Id. 
- The arbitrator was authorized to award any form of individual relief (and as Justice Scalia's opinion noted, this presumably included punitive damages); ${ }^{81}$

- AT\&T was not permitted to seek reimbursement from the consumer for its attorney's fees; ${ }^{82}$ and

- In the event that the consumer received an arbitration award greater than AT\&T's last written settlement offer, AT\&T was then required to pay a $\$ 7,500$ minimum recovery and twice the amount of the consumer's attorney's fees. ${ }^{83}$

All of these procedural specifics sound very good ${ }^{84}$ It is worth noting, however, that AT\&T inserted some of the most appealing terms only after the Concepcions filed their lawsuit. ${ }^{85}$ Apparently, the prospect of appearing before a judge and receiving a legally binding ruling incentivized the inclusion of these procedural specifics. ${ }^{86}$

The Ninth Circuit undertook some hard-headed risk analysis in reviewing some of the other terms in the clause, ultimately concluding that a consumer was terribly unlikely to receive the $\$ 7,500$ premium payment. ${ }^{87}$ If a consumer made a small claim in arbitration, for example, AT\&T could avoid paying the premium and the consumer's attorney's fees as long as it paid the face value of the claim at any point before the selection of the arbitrator. ${ }^{88}$ "Thus," according to the Ninth Circuit, "the maximum gain to a customer for the hassle of arbitrating a $\$ 30.22$ dispute is still just $\$ 30.22 . "$ " 89

The Ninth Circuit's analysis is not illogical, though it does ignore social science research showing that human beings are not entirely rational

81. Id.

82. Id.

83. Id.

84. There is room for debate, of course, on whether they are good enough, particularly in terms of providing consumers with sufficient access to legal information, legal advice and legal representation. See Tom Stipanowich et al., National Roundtable, supra note 50, at 22 (describing concerns regarding consumers' access to legal advice and representation).

85. Id.

86. See Laster v. T-Mobile USA, Inc., No. 05 cv1167 DMS (AJB), 2008 WL 5216255, at *11 (S.D. Cal. Aug. 11, 2008), rev'd sub nom. AT\&T Mobility LLC v. Concepcion, $131 \mathrm{~S}$. Ct. 1740 (2011).

87. See Laster v. AT\&T Mobility LLC, 584 F.3d 849, 855-56 (9th Cir. 2009), rev'd sub nom. AT\&T Mobility LLC v. Concepcion, 131 S. Ct. 1740 (2011).

88. Laster v. AT\&T Mobility $L L C, 584$ F.3d at 855-56.

89. Id. at 856 . 
as they make decisions. People still gamble in casinos after all. ${ }^{90}$ Indeed, Justice Scalia's opinion clarifies that in Concepcion, a class proceeding was not necessary because AT\&T had fashioned a sufficiently attractive and just bilateral proceeding as the substitute:

[T]he claim here was most unlikely to go unresolved. As noted earlier, the arbitration agreement provides that AT\&T will pay claimants a minimum of $\$ 7,500$ and twice their attorney's fees if they obtain an arbitration award greater than AT\&T's last settlement offer. The District Court found this scheme sufficient to provide incentive for the individual prosecution of meritorious claims that are not immediately settled, and the Ninth Circuit admitted that aggrieved customers who filed claims would be "essentially guarantee[d]" to be made whole.... Indeed, the District Court concluded that the Concepcions were better off under their arbitration agreement with AT\&T than they would have been as participants in a class action, which "could take months, if not years, and which may merely yield an opportunity to submit a claim for recovery of a small percentage of a few dollars." 91

Justice Scalia clearly acknowledges the importance of ensuring the attractiveness of alternative procedures and the likelihood that individual consumers will use them to effectuate their legal rights. ${ }^{92}$ Recent decisions in the Second Circuit signal that some courts are hearing that message. ${ }^{93}$

It could very well be that AT\&T's arbitration provision with its online elements, premium payment and potential reimbursement of attorney's fees would encourage consumers to make claims, thus benefitting themselves and alerting AT\&T to problem areas. ${ }^{94}$ If AT\&T then attended to those problem areas (perhaps with the help of an ombuds), ${ }^{95}$ the clause could have

90. See Russell Korobkin, Psychological Impediments to Mediation Success: Theory and Practice, 21 OHIO ST. J. ON DISP. RESOL. 281, 290-94 (2006) (generally describing optimistic overconfidence or overconfidence bias and applying it to mediation); Dan Simon, $A$ Third View of the Black Box: Cognitive Coherence in Legal Decision-Making, 71 U. CHI. L. REV. 511, 586 (2004) (" $[N]$ ovices and experts alike tend to distort the probability of winning toward optimistic overconfidence").

91. Concepcion, $131 \mathrm{~S}$. Ct. at 1753.

92. See id. at 1749 .

93. See In re Am. Express Merchs.' Litig., 667 F.3d at 219.

94. See Laster v. T-Mobile USA, Inc., 2008 WL 5216255, at*10-11.

95. If AT\&T chose to institutionalize an ombudsperson in addition to arbitration, for example, this neutral could collect data regarding arbitral claims and awards in order to make corporate officers aware-quickly-of emerging problems in a particular location or with a particular advertising campaign. The corporation could then take prompt corrective action, rather than waiting until it receives a demand letter threatening a class action. If such an ombudsperson is sufficiently independent and careful-and sufficiently supported by structural and procedural safeguards - she has the potential to serve many of the same public interests served by a private attorney general initiating, and a judge overseeing, a class action. 
the effect of encouraging responsive change and deterring bad conduct, thus achieving some of the most important effects of class actions. Seen in this light, granting class waiver could be quite reasonable. Rather than thinking of AT\&T as a company that required publicly-imposed coercive sanctions to deter bad behavior, such a dispute resolution clause and voluntary corrective action would signal a company that welcomes the opportunity to learn about problems from its customers and improve its goods and services. Such a customer-oriented approach may seem naïve, but it also makes good business sense.

If the clause makes this much sense, it then becomes clear that neither AT\&T nor any other company should be allowed to demand class waiver as the quid pro quo for the simple funding of a small claims court. Of course, this is just the sort of demand that the U.S. Chamber of Commerce, ${ }^{96}$ Wireless Association, ${ }^{97}$ DirecTV, Comcast and Dell ${ }^{98}$ made in their amicus briefs to the Court. In Concepcion, the Supreme Court did not need to bow before these threats. At the very least, it could have demanded more in return for consumers' loss of their right to aggregate small claims, especially when the potentially negative effects of such loss were to be compounded by deferential judicial review. In particular, the Supreme Court could have required that if a company seeks and wins a class waiver, any proposed substitute process must be 1) sufficiently attractive to

96. The Chamber observed that "[b]usinesses will likely forego arbitration entirely before they will choose to suffer class arbitration." Brief of the Chamber of Commerce of the U.S. as Amicus Curiae in Support of Petitioner, AT\&T Mobility LLC v. Concepcion, 131 S. Ct. 1740 (2011) (No. 09-893), 2010 WL 3167313 at $* 12$. The Chamber also pointed out, however, that "what makes class arbitration truly intolerable to many businesses is the nature of the adverse judgments it can produce. Like class litigation, class arbitration can cripple a business with a gargantuan judgment. But unlike class litigation, where appellate review of a court's certification and merits decisions is robust, the standard for vacating an arbitrator's decision is 'among the narrowest known to law." Id. at *14.

97. The Wireless Association's members include all of the major domestic cell phone providers. In its brief, the Association pointed out that businesses typically shoulder most of the costs associated with arbitration, in part because the benefits of individual arbitration make such a subsidization economically viable. If class procedures became allowable, regardless of the waiver language, the Association argued that there would no longer be any rational business incentive to subsidize the cost of arbitration. Brief of CTIA - The Wireless Association as Amicus Curiae in Support of Petitioner, AT\&T Mobility LLC v. Concepcion, 131 S. Ct. 1740 (2011) (No. 09-893), 2010 WL 3183858 at $* 21$.

98. Among other points, DirecTV, Comcast and Dell observed that Comcast and Amazon had decided to limit, or eliminate entirely, the use of consumer arbitration as a result of the Discover Bank case in California and the Scott case in Washington. Brief of Amici Curiae Directv, Inc, 2010 WL 3183855 , at ${ }^{*} 16$. They also urged that if companies discontinued their use of arbitration, consumers would be hurt due to increased prices. $I d$. at *19. 
encourage consumer complaints and the correction of problems, and 2) sufficiently fair in terms of both process and outcome. ${ }^{99}$

At one point in his opinion, though, Justice Scalia suggests that any old rough justice will do in arbitration as long as the process is streamlined, efficient, low cost and speedy. ${ }^{100}$ Indeed, he asserts that these are the "fundamental attributes" of arbitration, and anything that interferes with these attributes "creates a scheme inconsistent with the FAA."101 Such language has encouraged lower courts to interpret the "rules" apparently emerging from Concepcion as strikingly broad-brush and patently undemanding. ${ }^{102}$ One is that " $[\mathrm{w}]$ hen state law prohibits outright the arbitration of a particular type of claim, the analysis is straightforward: The conflicting rule is displaced by the FAA." 103 A second is that "[s]tates cannot require a procedure that is inconsistent with the FAA, even if it is desirable for unrelated reasons." "104 Many overburdened state and federal courts are using these sentences from Justice Scalia's opinion as they order consumers and employees away from the courts and away from class proceedings, into privatized bilateral arbitration. ${ }^{105}$ These courts are ignoring Justice Scalia's acknowledgement of the specifics of AT\&T's clause.

Such easy and undemanding diversion from the courts cannot last. If the Supreme Court is indeed providing an incentive for the private funding of an expanding layer of judicial adjuncts to conduct initial fact-finding, it will also inevitably be called upon to ensure that adjuncts' procedures meet at least the essential requirements of procedural due process. ${ }^{106}$ Most notable among these is a sufficiently impartial decision-maker and process. ${ }^{107}$ Such expectations will then require enforcement by someone. ${ }^{108}$

99. See Matthews v. Eldridge, 424 U.S. 319, 334-35, 343 (1976) ("An additional factor to be considered here is the fairness and reliability of the existing predetermination procedures, and the probable value, if any, of additional procedural safeguards.").

100. Concepcion, $131 \mathrm{~S}$. Ct. at 1749.

101. Id. at 1748 .

102. See Quilloin v. Tenet HealthSystem Philadelphia, Inc., 673 F.3d 221, 232-33 (3d Cir. 2012); Litman v. Cellco P'ship, 655 F.3d 225, 231 (3d Cir. 2011).

103. Concepcion, 131 S. Ct. at 1747; Kilgore v. KeyBank, Nat. Ass'n, 673 F.3d 947, 957, 960 (9th Cir. 2012).

104. Concepcion, 131 S. Ct. at 1753; In re Am. Express Merchs.' Litig., 667 F.3d at 213.

105. See Quillion, 673 F.3d at 232-33, 237.

106. Reuben, Constitutional Gravity, supra note 61 at 987-88. See also Welsh, Embedded Neutrals, supra note 31 at 407.

107. See Reuben, Constitutional Gravity, supra note 61 at 987-88; Goldberg v. Kelly, 397 U.S. 254 , 271 (1970) ("And, of course, an impartial decision maker is essential.").

108. See John Lande, Shifting the Focus from the Myth of "The Vanishing Trial" to Complex Conflict Management Systems, or I Learned Almost Everything I Need to Know About Conflict 
If, as the Supreme Court states in CompuCredit, the courts will be available to play this role only when and if consumers and other one-shot players choose to fight the enforcement of arbitral awards, ${ }^{109}$ the rigor of judicial review will become ever more important. Jurisprudence under the FAA, however, presents some unique challenges to achieving such rigor.

\section{JUdicial REVIEW OF ARBITRAL AwARDS}

The FAA provides for very limited grounds for the vacatur of arbitral awards and the standard for judicial review of arbitral awards is very deferential. ${ }^{110}$ Indeed, under the FAA, judges often must be more deferential to arbitrators than to other judges. Structural bias certainly is not listed as one of the grounds for vacatur. ${ }^{11}$ The ground for vacatur of arbitral awards that is closest to structural bias is "evident partiality," and courts have been very reluctant to find that structural bias meets the requirements of evident partiality. ${ }^{112}$ They have refused, for example, to vacate awards even when the arbitrator has been the employee of one of the parties, ${ }^{113}$ or when one of the parties has been represented on the governing board of the trade association that conducted the arbitration. ${ }^{114}$ With

Resolution from Marc Galanter, 6 CARDOZO J. CONFLICT RESOL. 191, 203, 206 (2005); Reuben, Constitutional Gravity, supra note 61, at 976-77; Sarah Rudolph Cole, Fairness in Securities Arbitration: A Constitutional Mandate?, 26 PACE L. REV. 73, 75 (2005-2006).

109. CompuCredit, 132 S. Ct. at 671.

110. See Welsh, Embedded Neutrals, supra note 31, at 417.

111. See id. at 404-05.

112. See id. at $417,417 \mathrm{n}$. $133,470 \mathrm{n}$. 458 . For several years, courts have used the state law of unconscionability to refuse to enforce mandatory predispute arbitration clauses. In Concepcion, however, the Supreme Court found evidence of judicial hostility to arbitration in Califormia courts' alleged tendency to be more likely to find contacts to arbitrate unconscionable than other contracts. Concepcion at 1747 (citing Broome, An Unconscionable Applicable of the Unconscionability Doctrine: How the California Courts are Circumventing the Federal Arbitration Act, 3 HASTINGS BUS. L.J. 39, 54, 66 (2006); Susan Randall, Judicial Attitudes Toward Arbitration and the Resurgence of Unconscionability, 52 BUFFALO L.REV. 185, 186-187 (2004)); see generally Hiro N. Aragaki, AT\&T Mobility v. Concepcion and the Antidiscrimination Theory of Federal Arbitration Act Preemption, 4 Y.B. Arb. \& Med. 2012 (2012), available at http://papers.ssrn.com/sol3/papers.cfm?abstract_id=2046453.

113. See, e.g., Westinghouse Elec. Corp. v. N.Y.C. Transit Auth., 623 N.E.2d 531, 533-34.

114. In Harter v. lowa Grain Co., 220 F.3d 544 (7th Cir. 2000), the parties to the arbitration were a corporation and a farmer. They arbitrated pursuant to an arbitration provision in a hedgeto-arrive (HTA) contract. The corporation was a member of the trade association designated to provide arbitration. One of the corporation's top employees sat on the trade association's board and the corporation paid more than $\$ 26,000$ annually in dues to the association. The trade association had taken the public position that the HTA contract did not represent a futures contract, which was an issue in the case. A significant portion of the association's members had written HTA contracts. The arbitral panel placed limits on the parties' ability to conduct discovery and eventually awarded attomeys' fees to the corporation without reviewing actual 
Concepcion and CompuCredit as the latest examples of the Supreme Court's intention to enforce the very arbitration clauses that other courts have found to be unconscionable or inconsistent with the substantive rights granted by federal statutes, the current deferential standard for the review of arbitral awards becomes ever more problematic. ${ }^{115}$ Indeed, judicial deference to arbitrators and the outcomes they produce becomes especially worrisome when arbitration draws its efficacy from the enforcement power of the state and the arbitrators' and arbitral organization's role is due to their special relationship with just one of the parties, usually the more powerful repeat player, in uneven contests between that repeat player and a one-time player. ${ }^{116}$ As I have written before:

This concern is especially strong when the one-time player is not as sophisticated as the repeat player, has not voluntarily or knowingly chosen the dispute resolution forum that will be used to resolve her dispute, and is either unaware of the special relationship between the neutral and the repeat player or aware of the relationship but effectively unable to challenge it. ${ }^{117}$

Some commentators have already begun to urge more rigorous judicial review in the disparate party context ${ }^{118}$ in light of the appropriateness and advantages of such rigor. ${ }^{119}$ Professor Sarah Cole has proposed that courts

billing records. Furthermore, the arbitral panel's decision was subject to review by the association's national secretary.

115. See Welsh, Embedded Neutrals, supra note 31, at 404-05.

116. See Nancy Welsh, Is The Supreme Court Demanding Enough As It Provides Incentives For The Private Funding of a Federal Small Claims Court?, SCOTUSblog (Sep. 21, 2011, 2:13 PM), http://www.scotusblog.com/2011/09/is-the-supreme-court-demanding-enough-as-itprovides-incentives-for-the-private-funding-of-a-federal-small-claims-court/; Welsh, Embedded Neutrals, supra note 31 .

117. Welsh, Embedded Neutrals, supra note 31, at 399.

118. See, e.g., Sarah Rudolph Cole, Revising the FAA to Permit Expanded Judicial Review of Arbitration Awards, 8 NEV. L.J. 214 (2007); Paul F. Kirgis, Judicial Review and the Limits of Arbitral Authority: Lessons from the Law of Contract, 81 ST. JOHN's L. REV. 99 (2007); Jeffrey W. Stempel, Keeping Arbitrations from Becoming Kangaroo Courts, 8 NEV. L.J. 251 (2007. 2008); Maureen A. Weston, The Other Avenues of Hall Street and Prospects for Judicial Review of Arbitral Awards, 14 LEWIS \& CLARK L. REV. 929 (2010).

119. See Chad M. Oldfather, Universal De Novo Review, 77 GEO. WASH. L. REV. 308, 319-20 (2009) (examining the underlying assumptions of universal de novo review by appellate courts, including: "(1) that there are correct answers to legal questions; (2) that those answers are ascertainable; (3) that those answers are articulable; and (4) that appellate courts are relatively more competent than trial courts at ascertaining and articulating those answers" due to structural advantages and their role in achieving the systemic needs of the legal system); Stephen I. Vladeck, Boumediene's Quiet Theory: Access to Courts and the Separation of Powers, 84 NOTRE DAME L. REV. 2107, 2145 (2009) (observing that if the denial of access to courts is understood as a separation-of-powers injury depriving the judiciary of its ability to check executive power, then "judicial review ensures that it is that courts, and not prison wardens or other executive branch officials, who decide the merits of the underlying claim." (emphasis added)). 
should use the arbitrary and capricious standard when reviewing arbitral awards that are accompanied by reasoned opinions. ${ }^{120}$ Professor Jeff Stempel has proposed that even though arbitrators' findings of fact should continue to be granted deference, their conclusions of law should be subjected to de novo review in the same manner as judicial awards. ${ }^{121}$ Both of these proposals, however, would require legislative action to amend the FAA. ${ }^{122}$ Such efforts have been stymied for years, ${ }^{123}$ and it is difficult to predict when the gridlock will end. ${ }^{124}$

Other academics have suggested that parties or judges could act to improve upon the current grounds for, and standards of, judicial review. Professor Maureen Weston has proposed that parties should be able to provide in their arbitration agreement that an arbitrator will be deemed to "exceed his authority" under state law if he issues a ruling that is not legally correct. $^{125}$ Professor Paul Kirgis, meanwhile, has urged that courts should

120. See Cole, Revising the FAA supra note 118 , at 232 (observing that such review would only be possible when awards were accompanied by reasoned opinions). But see Mandatory Arbitration Clauses: Proposals for Reform of Consumer-Defendant Arbitration, 122 HARV. L. REV. 1170, 1178 (2009) (observing that requiring a reasoned explanation "would likely improve the average accuracy of arbitration decisions, but it would also increase the costs of pursuing the claim in arbitration. . . . If the concern were simply to produce fair outcomes at any cost, this solution might be superior to the current system of arbitration, but, if that is the goal, both would be inferior to simply relying on courts in the first place. The essential goal of arbitration is to provide fair outcomes at a socially affordable price.").

121. Stempel, supra note 118, at 265-66; see also Darren P. Lindamood, Redressing the Arbitration Process: An Alternative to the Arbitration Fairness Act of 2009, 45 WAKE FOREST L. REV. 291, 312 (2010).

122. Cole, Revising the FAA, supra note 118, at 232-33; Stempel, supra note 118, at 257.

123. The Arbitration Faimess Act of 2009 failed to pass in the House of Representatives, but it was later reintroduced as the Arbitration Fairness Act of 2011, H.R. 1020, 112th Cong. (1st Sess. 2011).

124. There have been more targeted legislative successes, however. Indeed, Professor Cole's legislative proposal might have more traction if it was directed specifically toward consumer protection legislation. See Cole, Revising the FAA, supra note 118 , at 218 . In addition to more rigorous judicial review, commentators have proposed: state regulation of arbitrators, arbitration procedures and arbitral awards. See Stephen K. Huber, State Regulation of Arbitration Proceedings: Judicial Review of Arbitration Awards by State Courts, 10 CARDOzo J. CONFLICT RESOL. 509, 509, 511-13 (2009); Jean R. Sternlight, Creeping Mandatory Arbitration: Is it Just?, 57 STAN. L. REV. 1631, 1634-35 (2005). Some commentators have focused on the disclosure requirements for arbitral providers. See, e.g., Jaimie Kent, The Debate in California Over and Implications of New Ethical Standards for Arbitrator Disclosure: Are the Changes Valid or Appropriate?, 17 GEO. J. LEGAL ETHICS 903 (2004); see also Ruth V. Glick, California Arbitration Reform: The Aftermath, 38 U.S.F. L. REV. 119 (2003).

125. See Weston, supra note 118, at 951; see also Sean C. Wagner, Unchecked: How Frazier v. CitiFinancial Eliminated Judicially Created Grounds for Vacatur Under the Federal Arbitration Act, 64 OK. L. REV. 235, 249-55 (2012) (reviewing circuit split regarding whether manifest disregard fits within the ground for vacatur provided by FAA's Section 10(a)(4)—i.e., arbitrators exceeding their powers). But see Brian T. Burns, Note, Freedom, Finality, and Federal 
review arbitral awards for unconscionability just as they would the arbitration agreement, because the award is the creature of the contract between the parties. ${ }^{126}$

Despite the party-empowering underpinnings of arbitration, ${ }^{127}$ however, the Supreme Court held in Hall Street Associates, L.L.C. v. Mattel $^{128}$ that contracting parties do not have the authority to require more searching review from public courts. ${ }^{129}$ The Supreme Court in Hall even hinted that the courts reviewing arbitral awards pursuant to the FAA do not have the authority to develop their own, more searching standard of review, such as manifest disregard of the law. ${ }^{130}$ Continued judicial deference to arbitrators and their awards is apparently an integral and "fundamental" part of the FAA. ${ }^{131}$

\section{LOOKING FOR GUIDANCE IN OTHER AREAS OF JURISPRUDENCE THAT ARE CHARACTERIZED BY JUDICIAL DEFERENCE AND THE POTENTIAL FOR STRUCTURAL BIAS}

Importantly, the sort of structural bias that is so troubling in disparate party arbitration is neither a new problem nor one that is particularly unique to arbitration. ${ }^{132}$ There are other legal contexts in which Congress has explicitly authorized corporations and other organizations to select and fund their own decision-making tribunals. Such tribunals have then possessed the authority to make determinations regarding the corporations' or organizations' contractual obligations and have been granted deferential judicial review of their decisions. ${ }^{133}$ One such context involves private

Preemption: Seeking Expanded Judicial Review of Arbitration Awards Under State Law After Hall Street, 78 FORDHAM L. REV. 1813, 1816(2010).

126. See Kirgis, supra note 118; see also Huber, supra note 124, at 539-44 (proposing contract-based standards for judicial review of arbitration awards).

127. See Thomas E. Carbonneau, Judicial Approbation in Building the Civilization of Arbitration, 113 PENN. ST. L. REV. 1343, 1367 (2009).

128. 552 U.S. $576(2008)$.

129. Id. at 586,590 .

130. Id. at 584 .

131. See 9 U.S.C. $\$ \S 9-10$ (2006); see also Thomas S. Meriwether, Comment, Limiting Judicial Review of Arbitral Awards Under the Federal Arbitration Act: Striking the Right Balance, 44 HoUS. L. REV. 739, 766 (2007) (urging that "contractual agreements forgoing the right of appeal from a district court decision confirming or vacating an arbitral award should be enforced" but "agreements purporting to eliminate or limit the scope of a district court's review of an arbitral award should not").

132. See Welsh, Embedded Neutrals, supra note 31, at 405.

133. See Hall St. Assocs., L.L.C., 552 U.S. at 586-88; Anthony W. Rodgers, Procedural Protections During Medical Peer Review: A Reinterpretation of the Health Care Qualify Improvement Act of 1986, 111 PENN. ST. L. REV. 1047, 1047-48 (2006-2007). 
administrators' pension and disability benefit determinations pursuant to the Employee Retirement Income Security Act of 1974 ("ERISA"). ${ }^{134}$ Somehow, in this context, the Supreme Court has managed to acknowledge the existence of structural bias and make it a relevant and important factor to be considered as part of deferential judicial review. Further, the Supreme Court has provided guidance to lower courts regarding the weight to be given to structural bias in this context and has provided examples of the information required to assess such weight. Structural bias has been given the stature of tiebreaker in close cases. Finally and most important for the purposes of this Article, the Supreme Court has also incentivized the provision of structural and procedural safeguards in order to reduce the potency of the structural incentives that encourage biased decision-making. In other words, the Supreme Court has incentivized the provision of safeguards that will enhance the likelihood of accurate decision-making. All of this has occurred while maintaining a deferential standard of review. At this point, therefore, this Article will turn to judicial review of benefit denials in the ERISA context.

\section{A BRIEF EXAMINATION OF ERISA'S ACKNOWLEDGEMENT OF Structural Bias While RETAINING JUdiCIAL DEFERENCE}

The Supreme Court has observed that "ERISA represents a 'careful balancing""135 between encouragement of employers to provide pension, health and other employee benefit plans and the protection of employees' rights under such plans. ${ }^{136}$ Not surprisingly, employers and insurance companies have urged that if legislators and courts make "the provision of benefits too onerous, employers may simply decline to provide them." ${ }^{137}$ This is more than a little reminiscent of the warnings issued by the Chamber

134. Employee Retirement Income Security Act of 1974 (ERISA), Pub. L. No. 93-406, 88 Stat. 829 (codified as amended in scattered sections of 5 U.S.C., 18 U.S.C., 26 U.S.C., 29 U.S.C., and 42 U.S.C.).

135. See Conkright v. Frommert, 130 S. Ct. 1640, 1648-49 (2010) (citing Aetna Health Inc. v. Davila, 542 U.S. 200, 215).

136. See id.

137. See Katherine T. Vukadin, Delayed and Denied: Toward An Effective ERISA Remedy For Improper Processing of Healthcare Claims, 11 YALE J. HEALTH POL'Y L. \& ETHICS 331, 373 (2011) (citing Conkright v. Frommert, 130 S. Ct. 1640, 1648 (2010)); 29 C.F.R. \$ 2560.502-1(b) (2011) (noting the purely voluntary nature of the system); U.S. GEN. ACCOUNTING OFFICE, Health, Educ. \& Human SeRvs. Div., B-276104, EMPloyer-Based Managed Care Plans: ERISA'S EFFECT ON REMEDIES FOR BENEFIT DENIALS AND MEDICAL MALPRACTICE 16 (1998). 
of Commerce, Wireless Association, Directv, Comcast and Dell in their amicus briefs in Concepcion. ${ }^{138}$

Nonetheless, ERISA mandates the following: plans must provide employees with information regarding such plans' features and funding; those who manage and control plan assets bear fiduciary responsibilities ${ }^{139}$ and must establish a grievance and appeals process for participants who seek benefits; ${ }^{140}$ and employees who have been denied plan benefits have the right to challenge such denials in federal court. ${ }^{141}$ Importantly, however, ERISA does not specify the standard to be used by courts when reviewing challenges to administrators' benefit denials. ${ }^{142}$

In Firestone Tire and Rubber Co. v. Bruch, ${ }^{143}$ the Supreme Court turned to the principles of trust law to determine the appropriate standard of judicial review. ${ }^{144}$ The Court found, among other things, that a plan administrator's benefit determination should be understood as a fiduciary act, that the plan administrator is a fiduciary who owes a special duty of loyalty to plan beneficiaries, ${ }^{145}$ and that courts should use a de novo standard in reviewing an administrator's denial of benefits-unless the plan itself provides otherwise. ${ }^{146}$ Just as a court begins its assessment of a trustee's performance by turning to the provisions of the relevant trust document, a court reviewing a benefit administrator's decision must begin with the standard of review provided in the terms of the plan. ${ }^{147}$ Thus, if a plan grants discretionary authority to the administrator to determine whether a beneficiary's claim is eligible and valid, courts are required to use a deferential standard when reviewing a benefit denial. ${ }^{148}$

138. See supra notes $96-98$ and accompanying text. It appears that the Amicus Brief filed by CTIA, the Wireless Association in support of AT\&T, served as a source of inspiration for portions of Justice Scalia's opinion. Brief of CTLA - The Wireless Association as Amicus Curiae in Support of Petitioner, AT\&T Mobility LLC v. Concepcion, 131 S. Ct. 1740 (2011) (No. 09-893), 2010 WL 3183858.

139. See Employee Retirement Income Security Act of 1974 (ERISA), Pub. L. No. 93-406 (codified as amended in scattered sections of 29 U.S.C.); 29 U.S.C. $\$ 1104(\mathrm{a})(1)(2006)$.

140. Health Plans \& Benefits, U.S. DEP'T OF LABOR, http://www.dol.gov/dol/topic/healthplans/erisa.htm (last visited August 12, 2012).

141. 29 U.S.C. $\$ 1001(\mathrm{~b})(2006)$; see also $\$ 1132(\mathrm{a})(1)(\mathrm{B})$.

142. Firestone Tire \& Rubber Co., 489 U.S. at 109.

143. Firestone Tire \& Rubber Co. v. Bruch, 489 U.S. 101 (1989).

144. Id. at 110-11.

145. See John H. Langbein, Trust Law as Regulatory Law: The Unum/Provident Scandal and Judicial Review of Benefit Denials Under ERISA, 101 Nw. U. L. REV. 1315, 1326 (2007) (describing the care norm or duty of prudent administration as well as the loyalty rule).

146. Firestone Tire \& Rubber Co. at 102. See also Langbein, supra note 145 , at 1323.

147. Firestone Tire \& Rubber Co. at 102.

148. Id. 
Not surprisingly, most plans now grant discretionary authority to plan administrators, and thus deferential judicial review is the norm rather than the exception. ${ }^{149}$ Courts have used a variety of specific formulations- e.g., abuse of discretion, ${ }^{150}$ arbitrary and capricious, ${ }^{151}$ unreasonable ${ }^{152}$-but all are deferential. ${ }^{153}$ Once again, there are striking similarities here to the deferential standard of review used by courts when determining whether to vacate an arbitral award.

Judicial deference in the ERISA context is often problematic due to the pervasiveness of structural bias. ${ }^{154}$ Plan administrators generally are responsible for both determining the validity of an employee's claim and actually paying the amounts determined to be owed. The resulting structural bias is most obvious when the employer is also the plan administrator, responsible for funding the plan, evaluating claims and paying out benefits. ${ }^{155}$ "In such a circumstance, "every dollar provided in benefits is a dollar spent by. . . the employer; and every dollar saved. . . is a dollar in [the employer's] pocket. ... The employer's fiduciary interest may counsel in favor of granting a borderline claim while its immediate financial interest counsels to the contrary." 156 A very similar structural bias exists if a company provides an internal, company-sponsored arbitration process to decide debt collection matters and consumer claims.

Relying upon the trust law principles that are relevant in the ERISA context, the Supreme Court held in Firestone that an employer serving as plan administrator is operating under a conflict of interest, and such conflict has to be "weighed [by the reviewing court] as a "factor in determining whether there [was] an abuse of discretion"'157 by the employeradministrator who had denied an employee's claim for benefits.

But many employers turn to others, particularly insurance companies, and outsource responsibility for managing the plan funds, making benefit

149. See Langbein, supra note 145, at 1317 (objecting that the judicial deference shown in trust law to the wishes of transferors is due to the status of the normal private trust as "essentially a gift;" in contrast, ERISA's invocation of trust law was meant "to restrict rather than to promote the autonomy of the employer over its employee benefit plans.").

150. Id. at 1320; see also Green v. Union Sec. Ins. Co., 646 F.3d 1042 (8th Cir. 2011).

151. Langbein, supra note 145, at 1322; see also Durakovic v. Bldg. Serv. 32 BJ Pension Fund, 609 F.3d 133 (2d Cir. 2010).

152. Langbein, supra note 145, at 1339-40; see also Schexnayder v. Hartford Life and Acc. Ins. Co., 600 F.3d 465 (5th Cir. 2010).

153. Langbein, supra note 145 , at $1317,1321-22,1324$.

154. See id. at 1326.

155. Metropolitan Life Ins. Co. v. Glenn, 554 U.S. 105, 106 (2008).

156. Id. at 112 .

157. Firestone, 489 U.S. at 115 (quoting RESTATEMENT (SECOND) OF TRUSTS $\$ 187 \mathrm{cmt}$. d (1959)). 
determinations and distributing payments to beneficiaries. ${ }^{158}$ Obviously, there is an inherent potential for conflict of interest in the insurer's reliance on the employer for business. Arguably, though, this use of a third party should reduce the degree of conflict of interest or structural bias, in the same manner that the use of an outside arbitral organization should mitigate structural bias in consumer arbitration. Indeed, in the ERISA context, and despite the language of Firestone, some courts refused to acknowledge "inherent" or "simple and commonplace" bias as a conflict of interest, noting that the amount involved in an individual claim is often just too small to sway a decision-maker in light of many insurers' exponentially larger gross revenues, ${ }^{159}$ and the marketplace's punishment of any insurers who develop a reputation for self-interested errors in benefit determinations. ${ }^{160}$

But this faith in the selflessness of decision-makers, and in the rigor imposed by economies of scale and the market, has not always been justified. ${ }^{161}$ The existence and effects of structural bias among insurers in the ERISA context was revealed in 2002 , in a scandal involving the thenlargest American insurer specializing in disability insurance, Unum/Provident Corporation (Unum). ${ }^{162}$ At that time, evidence began to come to light that Unum had engaged in a variety of practices that might have helped it to maximize cost-effectiveness in claims processing ${ }^{163}$-but that also constituted abusive claims denials-e.g., pressuring its claimsprocessing employees to deny claims in order "to meet or surpass budget goals," 164 pressuring staff physicians to review claims too quickly to analyze them properly, not permitting physicians to request additional information or tests to aid their review of claims, and discouraging

158. See Vukadin, supra note 137 , at 339 ; Id. at 339-40.

159. See Langbein, supra note 145 , at $1327-28$.

160. See id. at 1328 .

161. Indeed, not all courts expressed this faith. The Tenth and Eleventh Circuits, for example, responded to structural bias by abandoning plan-mandated deferential review and shifting the burden to the administrator, as fiduciary, to show the reasonableness of a denial and its benefit to the class of beneficiaries. See Beverly Cohen, Divided Loyalties: How the Metlife v. Glenn Standard Discounts ERISA Fiduciaries' Canflicts of Interest, 2009 UTAH L. REV. 955, 96970 (2009) (discussing courts' disagreement on the existence of a conflict). The Ninth Circuit acknowledged the structural bias or "inherent" conflict as a factor to be considered. Id. at 965 .

162. See Langbein, supra note 145, at 1315. Other insurers had also engaged in conduct found to represent abusive denials of benefits. Id. at 1321-22 n. 41 .

163. Id. at 1315. See also Cohen, supra note 161, at 964 (describing how courts were reluctant to recognize a conflict when third-party administrators were making benefit denials, but some courts recognized that administrators might want to prove their cost-effectiveness in order to be rehired for another contract term or avoid determining third party claims in a manner inconsistent with the approach it used for another employer).

164. See Langbein, supra note 145 , at 1318. 
physicians from assisting beneficiaries to perfect their claims for disability insurance benefits. ${ }^{165}$ After litigation was commenced, discovery revealed a damning memorandum written by an Unum executive, in which the executive exulted over the advantages provided to the company by ERISA, including preemption of state law, abandonment of jury trials, banning of compensatory and punitive damages, and deferential judicial review. ${ }^{166}$ The memorandum observed, for example, that due to the deferential standard of review established by the Firestone court as applicable to benefit denials, Unum faced much less risk of liability than it otherwise would. ${ }^{167}$

Professor John H. Langbein detailed the Unum scandal in an article published in 2007. ${ }^{168}$ He then observed:

Broadly speaking, there are two plausible interpretations of the Unum/Provident scandal. Unum could be such an outlier that the saga lacks legal policy implications. On this view, a rogue insurance company behaved exceptionally badly, it got caught and was sanctioned, and its fate should deter others. The other reading of these events is less sanguine.... [C]onflicted plan decisionmaking is a structural feature of ERISA plan administration. The danger pervades the ERISA-plan world that a selfinterested plan decisionmaker will take advantage of its license under [Firestone v.] Bruch to line its own pockets by denying meritorious claims. Cases of abusive benefit denials involving other disability insurers abound. Unum turns out to have been a clumsy villain, but in the hands of subtler operators such misbehavior is much harder to detect. ${ }^{169}$

The Unum scandal was a dramatic wake-up call within the ERISA context-in much the same manner that the Minnesota Attorney General's action against National Arbitration Forum has served as a wake-up call regarding the dangers of structural bias in mandatory predispute consumer arbitration. ${ }^{170}$ Indeed, the parallels between these two cases are nearly overwhelming and will be discussed infra.

Nonetheless, over the years, a conflict had emerged among the federal circuits regarding whether structural bias should be considered a conflict in the ERISA context and, if it was, how it should affect the standard of review to be used by courts reviewing insurers' benefit denials. As noted supra, some federal circuits refused to recognize a standard or ubiquitous conflict as a conflict of interest. ${ }^{171}$ Other circuits took a very different

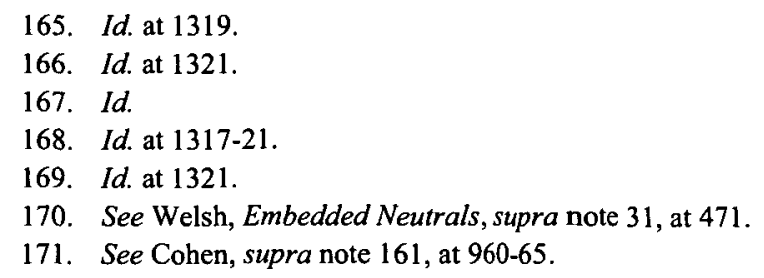


approach, responding to a showing of inherent conflict by shifting the burden to the insurer to show the reasonableness of its denial or adopting de novo and other non-deferential (even less than de novo) standards of review. ${ }^{172}$

In 2008, the Supreme Court responded to this split in the circuits with Metropolitan Life Insurance Co. v. Glenn. ${ }^{173}$ Metropolitan Life (MetLife) had served as the administrator and insurer of a Sears ERISA-governed disability insurance plan and had denied disability benefits to a Sears employee, Wanda Glenn. ${ }^{174}$ As is true in many of these cases, MetLife had determined that Glenn was entitled to disability insurance benefits for an initial 24-month period because she was unable to perform her particular job. ${ }^{175}$ At the conclusion of this 24 -month period, however, the plan provided that Glenn was entitled to continued disability benefits only if she could not perform any occupation for which she was qualified. ${ }^{176}$ MetLife denied Glenn's application for these benefits, finding that Glenn could perform in a sedentary occupation. ${ }^{177}$ Glenn challenged the denial in federal court. ${ }^{178}$ The District Court denied the employee's request for relief and entered judgment for the plan administrator. ${ }^{179}$ Using an abuse of discretion standard but treating MetLife's conflict of interest as a "relevant factor," the Sixth Circuit reversed and remanded. ${ }^{180}$ The Supreme Court affirmed. $^{181}$

In his majority opinion, Justice Breyer observed that with ERISA, Congress intended to "offer employees enhanced protection of their benefits." 182 He further observed that reliance on the protections offered by the market was insufficient due to employers' (and not employees') control of the selection of plan administrators and employers' potentially greater interest in low rates and premium payments than in accurate claims

172. See Cohen, supra note 161 , at $966-71$.

173. Metropolitan Life Ins. Co. v. Glenn, 554 U.S. 105 (2008).

174. Id. at 108-09.

175. Id. at 109 .

176. See id.

177. Id. MetLife had encouraged Glenn to apply for Social Security disability benefits and then chose to disregard the Social Security Administration's finding that Glenn could not work. MetLife also emphasized one physician report indicating the Glenn could work at the expense of other, more detailed medical reports and failed to provide all of the treating physician reports to its own hired experts. Finally, MetLife ignored evidence regarding the effects of stress upon Glenn. Id. at 110 .

178. Id.

179. Id.

180. Id. at $110-11$.

181. Id. at 119 .

182. Id. at 114 (citing Varity Co. v. Howe, 516 U.S. 489 (1996)). 
processing. ${ }^{183}$ Interestingly, Justice Breyer also observed that ERISA itself imposes fiduciary responsibilities on administrators, thus requiring "higherthan-marketplace quality standards." ${ }^{184}$ For purposes of ERISA, therefore, the Supreme Court held that when a structural conflict exists, it represents a conflict of interest that must be acknowledged. ${ }^{185}$ This holding was surprisingly significant. ${ }^{186}$ A structural bias that might be deemed "normal" or "unremarkable" in the context of a commercial contract was made "abnormal" or "aberrant" in the fiduciary context of ERISA. ${ }^{187}$

Based on the principles of trust law, however, the majority further concluded that the existence of such a conflict could not be permitted to trigger the "special burden of proof rules," 188 or "special procedural or evidentiary rules," 189 or the less deferential standards of review that several circuits had adopted. ${ }^{190}$ Justice Breyer explained that courts were required to continue to grant deference to administrators' decisions and reverse them only if they found abuse of discretion:

Trust law continues to apply a deferential standard of review to the discretionary decision making of a conflicted trustee, while at the same time requiring the reviewing judge to take account of the conflict when determining whether the trustee, substantively or procedurally, has abused his discretion." 191

But if reviewing courts are required to maintain deference as they review administrators' benefit denials, what meaningful role can structural bias or "inherent" conflict play in their disposition of the case? Firestone, after all, already required "the reviewing judge to take account of the conflict."

Justice Breyer rejected the parallels between ERISA-regulated obligations and contract law principles that had been urged by employers and insurers. ${ }^{193}$ Instead, Justice Breyer invoked courts' oversight of

183. Id.

184. Id. at 115

185. See id.

186. See id. at 116.

187. But see Cohen, supra note 161, at 991-92 (questioning whether ERISA beneficiaries are receiving a duty of loyalty from insurance fiduciaries if such insurers are processing both ERISA and non-ERISA claims in the same manner, with the same internal guidelines and claims processing software, and urging that claims processing should be conducted by randomly-assigned third parties).

188. Metropolitan Life Ins. Co., 554 U.S. at 116.

189. Id.

190. Id. at 116-17.

191. Id. at 115 .

192. Id.

193. Id. at 115-17. 
governmental officials' and administrative judges' decisions interpreting and enforcing the legal entitlements established by federal statute:

We believe that Firestone means what the word "factor" implies, namely, that when judges review the lawfulness of benefit denials, they will often take account of several different considerations of which a conflict of interest is one. This kind of review is no stranger to the judicial system. Not only trust law, but also administrative law, can ask judges to determine lawfulness by taking account of several different, often casespecific, factors, reaching a result by weighing all together. ... 194

Finally, Justice Breyer explained how administrators' conflicted decisionmaking-or structural bias-would factor into judicial review of administrators' denial of benefits:

... [A]ny one factor will act as a tiebreaker when the other factors are closely balanced, the degree of closeness necessary depending upon the tiebreaking factor's inherent or case-specific importance. The conflict of interest at issue here, for example, should prove more important (perhaps of great importance) where circumstances suggest a higher likelihood that it affected the benefits decision, including, but not limited to, cases where an insurance company administrator has a history of biased claims administration. ... 195

Chief Justice Roberts did not join this part of the Court's opinion because he found its requirement that courts consider the "mere existence of a conflict in every case" to be insufficiently "constrained"196 and thus likely to permit judges to engage in inappropriately "exacting scrutiny" of administrators' decision-making. ${ }^{197}$ Nonetheless, his concurrence provides several additional examples of structural bias that would suggest "a higher likelihood" of influencing the denial of benefits-and thus would support a finding of abuse of discretion. ${ }^{198}$ These examples include: evidence

194. Id. at 117 (citing RESTATEMENT (SECOND) OF CONFLICT OF LAWS $\$ 187$, cmt. b (1971)). Cf., e.g., Citizens to Preserve Overton Park, Inc. v. Volpe, 401 U.S. 402, 415-417 (1971) (reviewing governmental decision for abuse of discretion); Universal Camera Corp. v. NLRB, 340 U.S. 474 (1951) (reviewing agency factfinding).

195. Id.

196. Id. at 121 (Roberts, J., concurring).

197. Id. See also id. at 128 (Scalia, J., dissenting) (describing the majority's opinion as "nothing but de novo review in sheep's clothing" and proclaiming that "the notion that there are degrees of deference is absurd. . . . [T] he court either defers, or it does not. 'Some deference,' or 'less than total deference,' is no deference at all."); Cohen, supra note 161 at $990-91$ (expressing agreement with Scalia's analysis in his Glenn dissent that the decision offers courts the opportunity to engage in de novo review, but also observing that Glenn only "moves us closer to the de novo approach" and questioning "whether it achieves the 'undivided loyalty' that ERISA promises to plan beneficiaries").

198. Metropolitan Life Ins. Co., 554 U.S. at 120-22 (Roberts, J., concurring). 
regarding terms in a benefit plan that give "“a bonus for administrators who denied benefits to every $10^{\text {th }}$ beneficiary," bonuses to claims reviewers for "claims savings," or practice of unreasonably denying meritorious claims," ${ }^{, 201}$ and evidence of "a pattern of erroneous and arbitrary benefits denials, bad faith contract misinterpretations, and other unscrupulous tactics." ${ }^{\text {202 }}$ Graphically, this sort of evidence would be weighty enough to shift the scales of justice otherwise tipped deferentially toward the plan administrator.

In the majority opinion, meanwhile, Justice Breyer went further and provided instruction to administrators regarding their ability to influence the weight of a structural bias through the meaningful institutionalization of protections against structural bias:

It [the conflict at interest here] should prove less important (perhaps to the vanishing point) where the administrator has taken active steps to reduce potential bias and to promote accuracy, for example, by walling off claims administrators from those interested in firm finances, or by imposing management checks that penalize inaccurate decisionmaking irrespective of whom the inaccuracy benefits. . . ${ }^{203}$

Justice Breyer's wide-ranging citations to examples of structural safeguards may be almost as instructive as the explicit guidance contained in the words of the opinion supra. ${ }^{204}$ He referenced academics' recommendations that banks establish "interdepartmental information walls to reduce bank conflict"205 and that administrative agencies put into place "internal controls" to produce "administrative accuracy" $206 \mathrm{He}$ cited to the assertions in one of the amicus briefs that insurers have "incentives to reward claims processors for their accuracy." ${ }^{207}$ These structural safeguards would, of course, be in addition to ERISA's general requirement that plan administrators provide claimants with a reasoned basis, in writing, for the denial of benefits. ${ }^{208}$

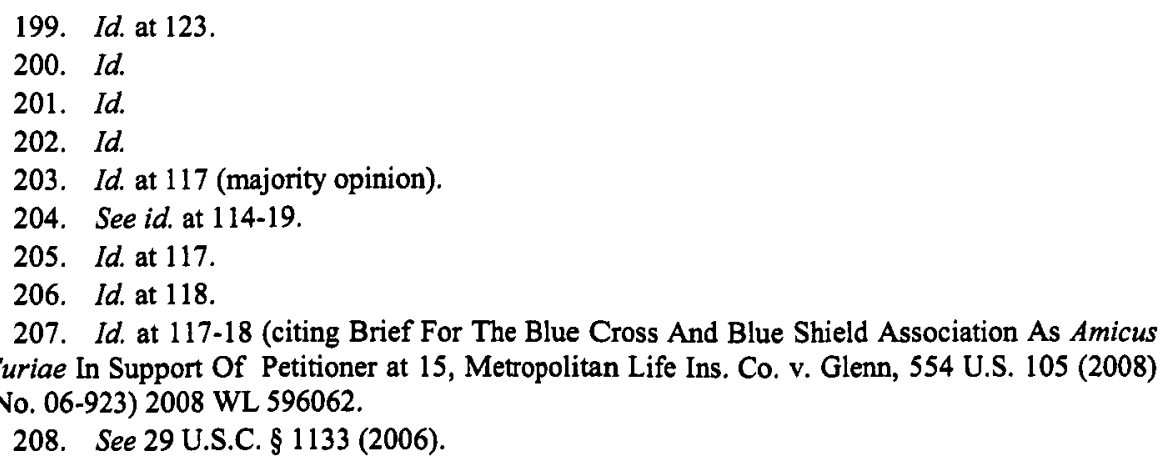


Following Glenn, ${ }^{209}$ most courts have accepted that ubiquitous conflicted decision-making is nonetheless a conflict. ${ }^{210}$ They have also accepted that they must use a deferential standard of review. ${ }^{211}$ With the notable exception of the Ninth Circuit, ${ }^{212}$ courts have not presumed that the existence of conflicted decision-making, by itself, will be enough to tip the balance of deferential review. Rather they have sought to assess the conflict's "weight" by examining whether: the structure of ERISA funds is such that a benefit denial will reduce the amounts paid by an employer into the plan; ${ }^{213}$ the savings produced by denials are likely to be significant to the employer ${ }^{214}$ or the insurer; ${ }^{215}$ administrators or outside reviewers sufficiently acknowledged contrary doctors' reports ${ }^{216}$ or awards from the Social Security Administration; ${ }^{217}$ and the number of referrals and amount

209. See Rosanne Marie Cross, Comment, ERISA for Dummies: Does MetLife Simplify and Clarify, 26 GA. ST. L. REV. 1335, 1344-52 (2010) (summarizing federal circuits' responses to Glenn).

210. See id. at 1344-53; Blankenship v. Metropolitan Life Ins. Co., 644 F.3d 1350 (11th Cir. 2011); Edwards v. Briggs and Stratton Retirement Plan, 639 F.3d 355 (7th Cir. 2011); Frankton v. Metropolitan Life Ins. Co., 432 Fed. App'x. 210 (4th Cir. 2011); Green v. Union Sec. Ins. Co., 646 F.3d 1042 (8th Cir. 2011); Salomaa v. Honda Long Term Disability Plan, 642 F.3d 666 (9th Cir. 2011); Cusson v. Liberty Life Assur. Co. of Boston, 592 F.3d 215 (1st Cir. 2010); Durakovic v. Bldg. Serv. 32 BJ Pension Fund, 609 F.3d 133 (2d Cir. 2010); Denmark v. Liberty Life Assur. Co. of Boston, 566 F.3d 1 (Ist Cir. 2009); Kiel v. Life Ins. Co. of North America, 345 Fed. App'x. 52 (2009). But see Eugene S. v. Horizon Blue Cross Blue Shield of N.J., 663 F.3d 1124, 1133 (2011) ("Asserting a conflict based on a generalized economic incentive, such as attracting more business through the denial of claims, without more, is 'insufficient to rise to the level of a legally cognizable conflict of interest."') (citing Finley v. Hewlett Packard Co. Empl. Benefits Org. Income Prot. Plan, 379 F.3d 1168, 1176 (10th Cir. 2004)).

211. Cross, supra note 209, at 1338-41; see also cases cited supra note 210.

212. See Salomaa, 642 F.3d at 675-76 (applying the abuse of discretion standard but "with the qualification that a higher degree of skepticism is appropriate when the administrator has a conflict of interest").

213. See Durakovic, 609 F.3d at 138-40 (citing Metropolitan Life Ins. Co., 554 U.S. at 128).

214. See Miller v. Am. Airlines, Inc., 632 F.3d 837, 847 (3d Cir. 2011) (observing that the American Airlines' benefit plan "lacked funds to meet a significant amount of its projected benefit obligation" and thus, "every dollar that American saved by reducing disability payments decreased its projected benefit obligation.").

215. See Blankenship v. Metropolitan Life Ins. Co., 644 F.3d 1350, 1357 (11th Cir. 2011) (acknowledging that every dollar not paid to a beneficiary is a dollar saved by MetLife in the short run).

216. See Miller, 632 F.3d at 843-44, 853-54 (illustrating how physicians appointed by American to evaluate a claimant's medical record came to different conclusions than the claimant's treating physician, despite acknowledging the claimant's treating physician's conclusion; the outside, appointed physicians' opinions were relied on by American, rather than the claimant's treating physician).

217. See Schexnayder v. Hartford Life \& Accident Ins. Co., 600 F.3d 465, 471 (5th Cir. 2010) (illustrating how Hartford ignored a Social Security Administration determination that the claimant was fully disabled and unable to perform work); see also Roy F. Harmon, The Debate Over Deference in the ERISA Setting - Judicial Review of Decisions by Conflicted Fiduciaries, 54 
of money paid by administrators to independent physicians was significant. $^{218}$ Although some courts have asserted that they are "dutybound to inquire into what steps a plan administrator has taken to insulate the decision-making process against the potentially pernicious effects of structural conflicts," 19 most courts have placed the burden squarely upon claimants to introduce evidence to substantiate the conflict's weight. ${ }^{220}$ This is, of course, a significant burden. ${ }^{221}$

But - and this is extraordinarily important in the context of disparate dispute resolution of any type-Glenn now entitles claimants to request discovery regarding the details of insurers' and employers' claims handling. ${ }^{222}$ Indeed, most of Chief Justice Roberts' examples of "weightier" structural bias described supra would require claimants challenging benefit denials to request, and courts to grant, targeted discovery that goes well beyond the "administrative record" established before the claims administrator. If access to information is power-and it is-there should be little wonder that Justice Scalia dissented in Glenn and so vehemently scorned both the majority's "fondness for a judge-liberating totality-of-the-circumstances 'test"" and his colleagues' apparent smallmindedness in presuming that "all fiduciaries with a conflict act in their selfish interest." 223

S.D. L. REV. 1, 23 (2009) ("Glenn provides a counterweight that may be employed to argue for greater development of the administrative record in the event a conflict of interest exists. In such cases, it may be argued that the plan administrator's failure to develop the record should constitute a factor in evaluating the reasonableness of the benefit denial.").

218. See Denmark v. Liberty Life Assur. Co., 566 F.3d 1, 5 (1st Cir. 2009) (illustrating how Liberty Life paid upwards of $\$ 2,000,000$ and referred 1,204 files to NMR physicians between 2001 and 2003).

219. Id. at 9; see also Schexnayder, 600 F.3d at 470 ("Hartford did not take any precautions to avoid or minimize the conflict resulting from its dual role as administrator and insurer of its disability plan and specifically did not "wall[ ] off claims administrators from those interested in firm finances or... impos[e] management checks that penalize inaccurate decisionmaking irrespective of whom the inaccuracy benefits.' (quoting Metropolitan Life Ins. Co, 554 U.S. at 117)).

220. See Denmark, 566 F.3d at 6; Cusson v. Liberty Life Assur. Co., 592 F.3d 215, 225 (1st Cir. 2010); Green v. Union Sec'y Ins. Co., 646 F.3d 1042, 1051-53 (8th Cir. 2011); Blankenship, 644 F.3d at 1355. But see Cohen, supra note 161, at 984-85 (urging that conflict of interest alone has not converted a reasonable fiduciary decision into an unreasonable one and that post-Glenn courts have resisted using conflict as a tiebreaker in close cases).

221. See Cohen, supra note 161 , at 956.

222. See Harmon, supra note 217 , at $24-25$ (describing post-Glenn discovery to supplement the administrative record and suggesting the potential application of administrative law-inspired principles and practices).

223. Id at 128,133 . Justice Scalia's presumption is diametrically opposed: "But if one is to draw any inference about a fiduciary from the fact that he made an informed, reasonable, though apparently self-serving discretionary decision, it should be that he suppressed his selfish interest 
Since Glenn was decided, courts have authorized the discovery requested by employees. ${ }^{224}$ In those few (and inevitably suspicious) instances when responses to court-ordered discovery have not been forthcoming, courts have also made adverse inferences regarding what they would have found. 225

Meanwhile, insurers and employers have taken the initiative to put into evidence the existence of structural safeguards, such as outside medical review of files, ${ }^{226}$ independent physician consultants' preparation of detailed reports acknowledging all available evidence and tests, ${ }^{227}$ an appeals process that involves different individuals than those who made the initial denial, ${ }^{228}$ the absence of contact between the plan administrator and the employer's financial advisors, ${ }^{229}$ and the absence of incentives to deny claims. ${ }^{230}$ Some courts have concluded that such structural and procedural safeguards make the existence of a conflict of interest insignificant, and have found no abuse of discretion. ${ }^{231}$ Other courts have found that such

(as the settlor anticipated) in compliance with his duties of good faith and loyalty. . . Only such a presumption can vindicate the trust principles and ERISA provisions that permit settlors to appoint fiduciaries with a conflict in the first place." Id. at 133-34. Justice Scalia's willingness to place nearly blind faith in conflicted fiduciaries is more than a little reminiscent of Justice White's similar faith in agency officials. See Welsh, Embedded Neutrals, supra note 31, at 446, 454-57, 459. And truthfully, it is not clear to this author that Justice Scalia read the final version of the majority opinion written by Justice Breyer and the nuanced weighting sketched there.

224. See, e.g., Denmark, 566 F.3d 1 at 10.

225. See, e.g., id. at 4-5. Discovery revealed that the insurer had referred 1,204 files and paid "upwards of $\$ 2,000,000$ to NMR physicians" during a two-year period; the court observed that the insurer had then "refused, on burdensomeness grounds, to answer interrogatories regarding the proportion" of referred files "in which claims had ultimately been allowed." The trial court drew the inference that NMR had found against the claimants, and for the plan, $100 \%$ of the time.

226. See, e.g., Miller, 632 F.3d at 843.

227. See, e.g., Frankton v. Metropolitan Life Ins. Co., 432 Fed. App'x. 210, 216 (4th Cir. 2011)

228. See Durakovic, 609 F.3d at 140 (also noting that the appeals panel included union and management representatives); Fortune v. Grp. Long Term Disability Plan for Emps. of Keyspan Corp., 637 F.Supp. 2d 132, 144 (E.D.N.Y.) (2009).

229. Fortune, 637 F.Supp. $2 \mathrm{~d}$ at 144.

230. See Edwards v. Briggs \& Stratton Ret. Plan, 639 F.3d 355, 365 (7th Cir. 2011); Fortune, 637 F.Supp. 2d at 144 (observing that Hartford had effectively "walled off" claims examiners from the company's finance department by ensuring that an examiner's compensation would not be based on his or her record of denying claims); see also Denmark, 566 F.3d at 10 (suggesting that "[i]n future cases, plan administrators, aware of Glenn, can be expected as a matter of course to document the procedures used to prevent or mitigate the effect of structural conflicts" with the information then included in the administrative record).

231. See, e.g., Frankton, 432 Fed. App'x. at 214, 216. 
safeguards can mitigate conflict, ${ }^{232}$ but some have taken pains to point out that the presence of such safeguards cannot be assumed to insulate an administrator from the existence of a conflict. ${ }^{233}$ Judicial review of the entire record is still required.

Has the structural bias that comes from conflicted decision-making, now acknowledged as a conflict of interest, actually served as a tiebreaker in close cases? Many would say not. ${ }^{234}$ Somehow, though, it is better than the bald-faced denial of conflict that went before. It is this clear-eyed acknowledgement of structural bias, and its potential to play the tiebreaker role, that could be exported into the arbitration jurisprudence. The clarity that comes with admitting the existence of conflict, combined with the potential transparency and accountability offered by discovery into administrators' claims processing, would at least create the potential to enhance the reality of, and a skeptical public's perception of, the thoroughness and accuracy of decision-making in mandatory predispute arbitration.

\section{APPLICATION TO MANDATORY PREDISPUTE CONSUMER ARBITRATION}

Structural bias has the potential to affect third party arbitral organizations just as much as it has the potential to affect third party insurers making benefit determinations. ${ }^{235}$ Indeed, the cautionary tale of the National Arbitration Forum ("NAF"), which once handled the majority of consumer arbitrations, ${ }^{236}$ reveals the potential for structural bias. Admittedly, the allegations contained in the Minnesota Attorney General's complaint were never tested by a motion to dismiss, and the case never went to trial or even summary judgment. ${ }^{237}$ Nonetheless, the complaint and newspaper reports combined to paint a picture of a complex web of private actors and overlapping financial and business relationships, all

232. See Eugene v. Horizon Blue Cross Blue Shield of N.J., 663 F.3d 1124, 1133 (10th Cir. 2011) (citing Finley v. Hewlett-Packard Co. Emp. Benefits Org. Income Prot. Plan, 379 F.3d 1168,1176 (10th Cir. 2004)).

233. See Miller, 632 F.3d at $847-48$ (observing that the medical review by third party Western Medical Evaluators had occurred after the termination of benefits and that it was not binding because American could seek further review of the report's conclusions if it was dissatisfied with the analysis).

234. See, e.g., Cross, supra note 209, at 1359 (urging a return to the principles of trust law requiring an actual conflict, in order to "[s]ave time, preserve judicial resources, and establish clarification for ERISA claimants and administrators."); Conkright v. Frommert, $130 \mathrm{~S}$. Ct. 1640 (2010).

235. See Welsh, Embedded Neutrals, supra note 31, 399-402.

236. See id. at 427-30.

237. See id. at 430 . 
"motivated. . .by a shared pecuniary interest in ensuring that consumer arbitration assisted the debt collection process and the production of profits for all of the investors associated with that process."238 Credit card companies brought their collection matters to Mann Bracken, the large law firm, for debt collection. ${ }^{239}$ If they were unsuccessful, the Mann Bracken lawyers referred the cases to the for-profit NAF for arbitration (which had advertised arbitration to credit card companies as a means to get customers to "basically hand you the money"). NAF and Forthright (a new company created by NAF and the private equity firm of Accretive to handle the financial aspects of NAF's operation) were responsible for making the referrals to NAF's pool of arbitrators, one of whom allegedly stopped receiving referrals after she found for a customer and against a credit card company on a relatively substantial counterclaim. ${ }^{240}$ The arbitrators then conducted arbitration proceedings - - and found for the credit card companies nearly $95 \%$ of the time. ${ }^{241}$ The credit card companies then turned to the courts, which transformed the arbitral awards into judgments. ${ }^{242}$ Axiant, another new company created by Accretive and members of Mann Bracken, then took over and proceeded to collect on the judgments. ${ }^{243}$ In this picture, $\mathrm{NAF}$ and arbitration were no longer focused on dispute resolution as an end in and of itself. Rather, NAF had joined with Accretive and Mann Bracken to exploit consumer arbitration's "billion-dollar business" potential, as imagined by Accretive. ${ }^{244}$

Importantly, NAF quickly settled with the Minnesota Attorney General. ${ }^{245}$ The organization is no longer providing consumer arbitration services. $^{246}$ It is tempting for many dispute resolution proponents to understand NAF as an aberration. Likely, many in the ERISA context view Unum similarly, as an outlier or a rogue. It becomes tempting to do nothing, to assume the culprit has been found, and the crisis has been averted. That could be exactly right.

But Glenn and its progeny in the ERISA context make it clear that it is also possible to choose to be more proactive than that. It is possible for courts to continue to grant deferential review to arbitral awards, as required

\footnotetext{
238. Id. at $427-30,467$.

239. Id. at 429-30.

240. Id. at 437-38.

241. Id. at 430 .

242. Id.

243. Id.

244. Id. at 428,430 .

245. Id.

246. Id.
} 
by the FAA, while also subjecting the evidence of structural bias to more rigorous examination. Further, Glenn suggests that structural bias can and should be understood as "evident partiality." The rigor comes in the next step-in assessing the gravity, or weight, of such partiality. ${ }^{247}$ Just as many do in the context of ERISA, courts can place the burden of demonstrating the severity of the partiality upon consumers (and employees, nursing home patients and any others subject to mandatory predispute arbitration clauses in adhesive contracts). But they would also need to be more willing to grant consumers (and employees, nursing home patients and others involved in disparate party arbitration) the right to pursue post-award discovery into corporations', agencies' and arbitral firms' management of their arbitration procedures. ${ }^{248}$ And if the resulting evidence demonstrates partiality that has a "high likelihood" of influencing arbitral decisionmaking, courts could and should refuse to enforce the resulting arbitral awards.

At this point, it makes sense to return to the clause at issue in Concepcion. Earlier, this Article noted that the provisions of the clause are likely to encourage consumers to pursue their individual claims. ${ }^{249}$ But are the clause's provisions also sufficiently likely to "reduce potential bias and promote accuracy" in the arbitral process? Based on the Supreme Court's description of the clause in Concepcion, we know that if a consumer's claim reaches arbitration, the consumer can choose the form of arbitration that she would prefer-i.e., in person, by telephone or based only on paper submissions. ${ }^{250}$ We also know that the arbitration must occur in the county in which customer was billed. ${ }^{251}$ These provisions appear quite reassuring.

247. See Metropolitan Life Ins. Co., 554 U.S. at 106; see also AT\&T Mobility LLC, 131 S. Ct. at 1752 (citing 9 U.S.C. $\S 10(2002)$ ).

248. Courts currently grant post-arbitral award discovery sparingly and require the party who seeks discovery to demonstrate "clear evidence of impropriety" or first make out a preliminary or prima facie case to vacate the award. See, e.g., Midwest Generation EME, LLC v. Continuum Chemical Corporation, 768 F. Supp.2d 939, 943, 946 (N.D. Ill. 2010) (refusing to permit party to take post-award discovery when party was seeking vacatur based on evident partiality; explaining that party had failed to meet the "clear evidence" standard and that relaxing the standard would undermine arbitration's "essential virtue of resolving disputes straightaway"); Vollers Excavating \& Const., Inc. v. Watchung Square Associates, L.L.C., No. L-547-02, 2009 WL 2208563 at *10 (N.J. Super. Ct. App. Div. Jul. 27, 2009) (finding that party seeking post-award discovery had failed to make out prima facie case of undisclosed bias sufficient to support a finding of evident partiality); Antietam Indus., Inc. v. Morgan Keegan \& Co., Inc., No. 6:12-cv-1250-Orl-36TBS, 2012 WL 4513763 (M.D. Fla. Oct. 2, 2012) (permitting post-award discovery). The heightened potential for structural bias in disparate party arbitration could be found sufficient to make out a preliminary or prima facie case.

249. See supra notes 18-19 and accompanying text.

250. See supra notes $76-83$ and accompanying text.

251. See supra note 78 and accompanying text. 
By providing the consumer with the opportunity to tailor the proceeding to her capacities and circumstances, these provisions are likely to enhance her ability to be heard ${ }^{252}$ and thus promote the accuracy of a final decision.

AT\&T's clause also provides that the consumer can choose to sue in small claims court rather than arbitration. ${ }^{253}$ On its face, this provision is also reassuring because it provides the consumer with an opt-out from arbitration. Indeed, this provision seems to harness the power of healthy competition between public courts and private arbitration providers. But we would need to know more about the small claims courts available to the consumer. These courts tend to have low jurisdictional caps. Further, as states have reduced funding for their courts, some courts have been forced to reduce their hours or even close for full days during the week. ${ }^{254}$ Obviously, such an operational change has the potential to reduce consumers' access to small claims courts. Thus, it is not clear whether the opt-out provision in AT\&T's clause would actually have the effect of reducing bias and promoting accuracy. It depends.

Last and perhaps most strikingly, though, the clause at issue in Concepcion provides that if the consumer receives an arbitration award greater than AT\&T's last written settlement offer, AT\&T must pay a $\$ 7,500$ minimum recovery to the consumer and twice the amount of the consumer's attorney's fees. ${ }^{255}$ On its face, this last provision would seem quite likely to reduce potential bias - but, again, we would need to know much more about the details of these provisions' implementation. Does AT\&T have written policies (or performance evaluation factors) to guide employees' decisions regarding the amount of their first settlement offers to consumers? Do such policies exist for subsequent settlement offers? On average, how many times must a consumer refuse AT\&T's settlement offers in order to be offered the full amount of her claim? Do AT\&T's employees tend to wait until just before the selection of the arbitrator to offer the full amount requested by a consumer? How is the available pool of arbitrators selected

252. See Goldberg v. Kelly, 397 U.S. 254, 268-69 (1970) ("The opportunity to be heard must be tailored to the capacities and circumstances of those who are to be heard").

253. See supra note 80 and accompanying text.

254. See AMERICAN BAR ASSOCIATION TASK FORCE ON THE PRESERVATION OF THE JUSTICE SYSTEM, Report, Crisis in the Courts: Defining the Problem at 3 (2012) (observing that "fourteen state court systems have been forced to curtail the hours and even entire days they are open"); Gregory J. Linhares \& Anne Dannerbeck Janku, "Show Me" Where It Hurts: The Missouri Approach to Budget Impact Analysis, in NAT'L CTR. FOR STATE COURTS, FUTURE TRENDS IN STATE COURTS 2010 80, 82 (Carol R. Flango et al. eds., 2010) (describing process in which Missouri identified small claims matters as low priority and proposed staffing cuts that would either delay or deny case processing), available at http://cdml6501.contentdm.oclc.org/cdm/ ref/collection/ctadmin/id/1605.

255. See supra note 83 and accompanying text. 
for these types of cases? How are arbitrators selected for particular cases? What is the contractual and financial relationship between AT\&T and its arbitral provider(s) ${ }^{256}$ How significant is AT\&T's share of each arbitral provider's gross and net revenues? ${ }^{257}$ Is there the potential for the arbitral provider, or individual arbitrators, to receive bonuses for their work for AT\&T? If yes, what is the basis for those bonuses? What information does AT\&T receive about the claims made by consumers, the results of these claims and the arbitrators responsible for deciding the claims? How has AT\&T used this information? Has AT\&T ever used this information to improve its products or services? ? $^{258}$ If yes, in what way has AT\&T used this information to improve its services? Etc. These sorts of details inevitably will matter in determining whether the clause's provisions will have the effect of reducing bias-or enhancing it.

There are important differences, of course, between the ERISA and consumer contexts. The ERISA jurisprudence recognizes that employees, beneficiaries, and the funds collected on their behalf need protection, and administrators are therefore obligated to operate as fiduciaries. ${ }^{259}$ In

256. Principles II and V of the Georgetown CPR Principles for ADR Provider Organizations, supra note 67 , which recommend disclosure by dispute resolution organizations, also suggest many more questions of this type:

II. Information Regarding Services and Operations ADR Provider. Organizations should take all reasonable steps to provide clear, accurate and understandable information about the following aspects of their services and operations:

a. The nature of the ADR Provider Organization's services, operations, and fees;

b. The relevant economic, legal, professional or other relationships between the ADR Provider Organization and its affiliated neutrals;

c. The ADR Provider Organization's policies relating to confidentiality, organizational and individual conflicts of interests, and ethical standards for neutrals and the Organization;

d. Training and qualifications requirements for neutrals affiliated with the Organization, as well as other selection criteria for affiliation; and

e. The method by which neutrals are selected for service.

V. Disclosure of Organizational Conflicts of Interest. The ADR Provider Organization should disclose the existence of any interests or relationships which are reasonably likely to affect the impartiality or independence of the Organization or which might reasonably create the appearance that the Organization is biased against a party or favorable to another, including (i) any financial or other interest by the Organization in the outcome; (ii) any significant financial, business, organizational, professional or other relationship that the Organization has with any of the parties or their counsel, including a contractual stream of referrals, a de facto stream of referrals, or a funding relationship between a party and the organization; or (iii) any other significant source of bias or prejudice concerning the Organization which is reasonably likely to affect impartiality or might reasonably create an appearance of partiality or bias.

257. My thanks go to Professor Jeffrey Stempel for suggesting this question long ago.

258. See e.g., supra note 95 (regarding potential use of ombuds).

259. See Langbein, supra note 145, at 1325-28. The loyalty rule "requires plan fiduciaries to act 'solely in the interest of the participants and beneficiaries and . . for the exclusive purpose of ... providing benefits to participants and their beneficiaries. ." Id. at 1326 . Thus administrators in the ERISA context are legally barred from acting in the self-interested, selfish manner that can characterize the contractual relations of commercial parties-and may violate relational norms. 
consumer litigation, American judges have not traditionally been understood as fiduciaries. They do, however, serve in this role in some contexts, particularly when individual unsophisticated one-shot players are perceived as vulnerable to self-interested repeat players. ${ }^{260}$ There are some calls for judges to imagine themselves as fiduciaries more frequently. ${ }^{261}$

If we turn specifically to arbitral organizations and arbitrators, meanwhile, there is no language in the FAA or in the Supreme Court's arbitral jurisprudence that establishes a fiduciary duty for them, under any circumstances. $^{262}$ There is nothing, for example, instructing arbitrators that they owe a special duty to consumers or employees in disparate party arbitration - or that in the case of a close call, they should err on the side of those who are to be served by federal statutes specially enacted to protect vulnerable people from employment discrimination, consumer fraud, or mental or physical abuse. It should not be surprising that such language is missing from the FAA. It was originally enacted to overcome judicial hostility to the arbitration clauses that had been negotiated by sophisticated commercial parties. ${ }^{263}$ In light of the Supreme Court's jurisprudence that has expanded the FAA to the disparate party context, it would make sense for Congress to amend the FAA to provide that in certain specified contexts-e.g., arbitration of employment discrimination and consumer

See Wible v. Aetna Life Ins. Co., 375 F.Supp. 2d 956, 969 (C.D. Cal. 2005) (finding that the record reflected un-rebutted material and probative evidence that tended to show Aetna's selfinterest caused a breach of its fiduciary obligations to the disability claimant). See also Amy J. Schmitz, Consideration of "Contracting Culture" in Enforcing Arbitration Provisions, 81 SAINT JOHN'S L. REV. 123, 158 (2007).

260. See, e.g., Reynolds v. Beneficial Nat'l Bank, 288 F.3d 277, 279-80 (7th Cir. 2002) (describing judge as fiduciary in determining whether to approve class settlement); see also Lisa L. Casey, Reforming Securities Class Actions from the Bench: Judging Fiduciaries and Fiduciary Judging, 2003 B.Y.U. L. REV. 1239 (2003); Alexandra N. Rothman, Bringing an End to the Trend: Cutting Judicial Approval and Rejection Out of Non-Class Mass Settlement, 80 FORD. L. REV. 319 (2011); Hillary A. Sale, Judges Who Settle, 89 WASH. U. L. REV. 377, 389-90 (2011).

261. See, e.g., Ethan J. Leib, David L. Ponet \& Michael Serota, A Fiduciary Theory of Judging, _ CALIF. L. REV. _ (forthcoming) (urging that using the principle of fiduciary relationships assists with a better conceptualization of the judicial role).

262. Interestingly, Professor Jacqueline Nolan-Haley has suggested that mediators play a fiduciary role. See Jacqueline M. Nolan-Haley, Informed Consent in Mediation: $A$ Guiding Principle for Truly Educated Decisionmaking, 74 NOTRE DAME L. REV. 775, 825-26 (1999) (suggesting that a mediator occupies a position of trust and has special fiduciary relationship to both parties in a dispute). See also Nancy A. Welsh, The Thinning Vision of Self-Determination in Court-Connected Mediation: The Inevitable Price of Institutionalization?, 6 HARV. NEGOT. L. REV. 1, 84-86 (2001) (discussing the related concept of undue influence and exploring whether a mediated settlement agreement could be set aside based on a mediator's undue influence over a party).

263. See Scherk v. Alberto-Culver Co., 417 U.S. 506, 510 (1974) (noting that the Federal Arbitration Act reversed centuries of judicial hostility to arbitration agreements). 
matters conducted pursuant to mandatory predispute arbitration clauses in contracts of adhesion - arbitral organizations and arbitrators are obligated to act as fiduciaries, with higher-than-marketplace quality standards.

Even in interpreting the current language of the FAA, however, courts could read a fiduciary understanding into the provisions regarding evident partiality or arbitrators exceeding their powers, as responsibility for the protection of consumers, employees and vulnerable others migrates from private attorneys general battling on behalf of their clients to the factfinding judicial adjuncts handling the many "smaller" cases-involving messy human dynamics and small financial stakes-that courts perceive they can no longer handle. If these cases must go to arbitration, it makes just as much sense in this context as in the ERISA context to import at least some of the fiduciary guidance and treatment of structural conflict offered by MetLife v. Glenn.

\section{CONCLUSION}

Either with help from the Congress or without it, our society needs our courts to play their essential role in providing the less-powerful with meaningful access to a forum where the heady promises contained in legislation will be aired and compared to reality, where meaningful redress is possible, and ultimately, where the less-powerful can experience justice. If the Supreme Court is indeed incentivizing the creation of a national, private small claims court, it also must assume responsibility for assuring the sufficiency of the justice-procedural and substantive-provided by such a court. The Supreme Court can look to its own jurisprudence-the model in Glenn-for guidance. This model was itself inspired by administrative agencies' and regulated industries' practices. It represents one means to continue to use a deferential standard of judicial review, while also acknowledging that reliance on privatized tribunals inevitably leads to perceptions of structural bias and the unacceptably high likelihood of actual bias-and thus, must be addressed. The model offered by Glenn is also useful because it assumes that as part of courts' reviewing function, they can and should incentivize the development of procedural safeguards that reduce the effects of bias and promote accurate decision-making. Finally, the model offered by Glenn harnesses private initiative to bring transparency and accountability to privatized procedures-by encouraging consumers (and their lawyers) to demand discovery regarding arbitral providers' internal operations.

These sorts of procedural safeguards, at the very least, are what the valuable bargaining chip of class waiver should be able to buy. 